\title{
Neurobiology
}

PERGAMON

\section{Neuroprotection by estradiol}

\author{
Luis Miguel Garcia-Segura ${ }^{\mathrm{a}}$, Iñigo Azcoitia ${ }^{\mathrm{b}}$, Lydia L. DonCarlos ${ }^{\mathrm{c}, *}$ \\ ${ }^{\mathrm{a}}$ Instituto Cajal, C.S.I.C., E-28002, Madrid, Spain \\ ${ }^{\mathrm{b}}$ Biologia Celular, Facultad de Biologia, Universidad Complutense, E-28040 Madrid, Spain \\ ${ }^{\mathrm{c}}$ Department of Cell Biology, Neurobiology and Anatomy, Loyola University Chicago, Stritch School of Medicine, 2160 South First Avenue, \\ Maywood, IL 60153, USA
}

Received 3 March 2000

\begin{abstract}
This review highlights recent evidence from clinical and basic science studies supporting a role for estrogen in neuroprotection. Accumulated clinical evidence suggests that estrogen exposure decreases the risk and delays the onset and progression of Alzheimer's disease and schizophrenia, and may also enhance recovery from traumatic neurological injury such as stroke. Recent basic science studies show that not only does exogenous estradiol decrease the response to various forms of insult, but the brain itself upregulates both estrogen synthesis and estrogen receptor expression at sites of injury. Thus, our view of the role of estrogen in neural function must be broadened to include not only its function in neuroendocrine regulation and reproductive behaviors, but also to include a direct protective role in response to degenerative disease or injury. Estrogen may play this protective role through several routes. Key among these are estrogen dependent alterations in cell survival, axonal sprouting, regenerative responses, enhanced synaptic transmission and enhanced neurogenesis. Some of the mechanisms underlying these effects are independent of the classically defined nuclear estrogen receptors and involve unidentified membrane receptors, direct modulation of neurotransmitter receptor function, or the known anti-oxidant activities of estrogen. Other neuroprotective effects of estrogen do depend on the classical nuclear estrogen receptor, through which estrogen alters expression of estrogen responsive genes that play a role in apoptosis, axonal regeneration, or general trophic support. Yet another possibility is that estrogen receptors in the membrane or cytoplasm alter phosphorylation cascades through direct interactions with protein kinases or that estrogen receptor signaling may converge with signaling by other trophic molecules to confer resistance to injury. Although there is clear evidence that estradiol exposure can be deleterious to some neuronal populations, the potential clinical benefits of estrogen treatment for enhancing cognitive function may outweigh the associated central and peripheral risks. Exciting and important avenues for future investigation into the protective effects of estrogen include the optimal ligand and doses that can be used clinically to confer benefit without undue risk, modulation of neurotrophin and neurotrophin receptor expression, interaction of estrogen with regulated cofactors and coactivators that couple estrogen receptors to basal transcriptional machinery, interactions of estrogen with other survival and regeneration promoting factors, potential estrogenic effects on neuronal replenishment, and modulation of phenotypic choices by neural stem cells. (C) 2000 Elsevier Science Ltd. All rights reserved.
\end{abstract}

Abbreviations: AF64, ethylcholine aziridinium; ApoE, apolipoprotein E; ARA-70, androgen receptor associated protein-70; AvPv, anteroventral periventricular nucleus; BDNF, brain derived neurotrophic factor; BrdU, bromodeoxyuridine; $\mathrm{CHO}$, Chinese hamster ovary; EGF, epidermal growth factor; ER, estrogen receptor; ERE, estrogen response element; FGF, basic fibroblast growth factor; GABA, gamma amino butyric acid; GAP-43, growth associated protein-43; GAT-1, GABA transporter 1; IGF-I, insulin-like growth factor-I; IGF-IR, insulin-like growth factor-I receptor; MAPK, mitogen-activated protein kinase; MPTP, 1-methyl-4-phenyl-1,2,3,6-tetrahydropyridine; NMDA, $N$-methyl-D-aspartic acid; Par-4, prostate associated response-4; SERMS, selective estrogen receptors modulators; SDN-POA, sexually dimorphic nucleus of the preoptic area.

* Corresponding author. Tel.: + 1-708-216-4975; fax: + 1-708-216-3913.

E-mail address: ldoncar@luc.edu (L.L. DonCarlos). 


\section{Contents}

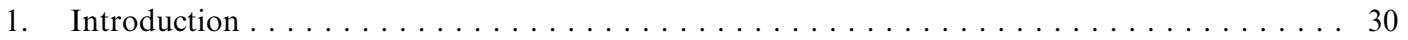

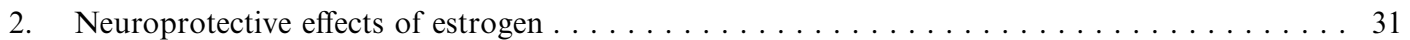

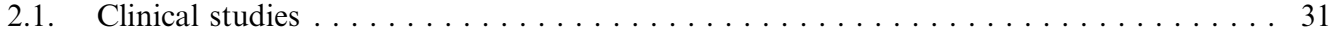

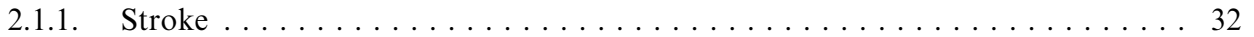

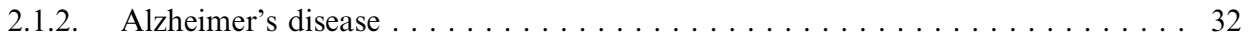

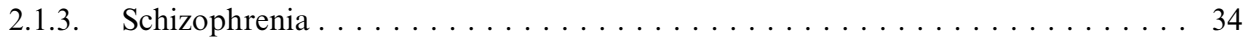

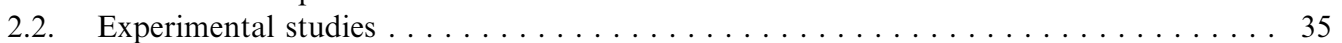

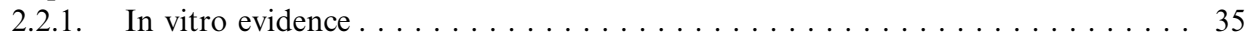

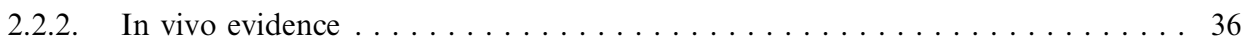

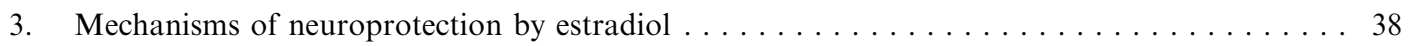

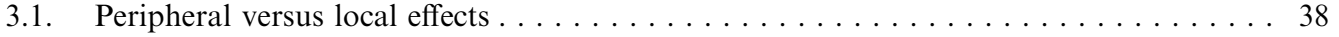

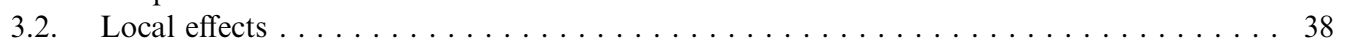

3.2.1. Mechanisms independent of the transcriptional activation by estrogen receptors 38

3.2.2. Mechanisms mediated by the activation of estrogen receptors and gene

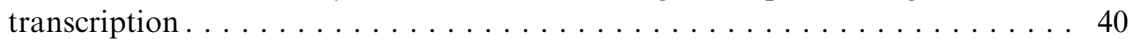

3.2.3. Potential molecular targets of estrogen receptor-mediated neuroprotection. . . 44

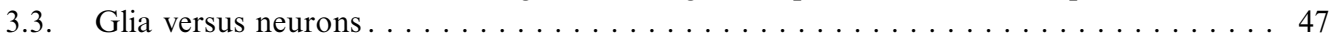

4. Prospectives for future studies $\ldots \ldots \ldots \ldots \ldots \ldots \ldots \ldots \ldots \ldots \ldots \ldots \ldots \ldots$

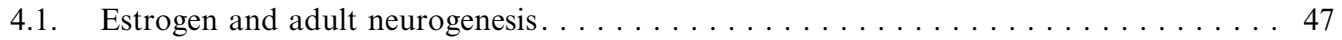

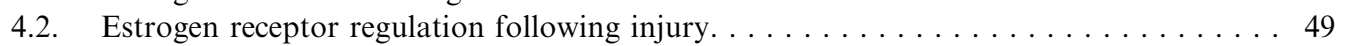

4.3. Estrogenic ligands, receptors, and other mechanisms of action . . . . . . . . . 49

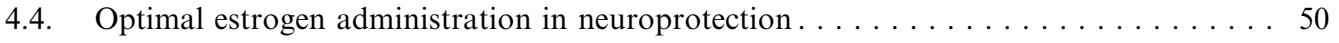

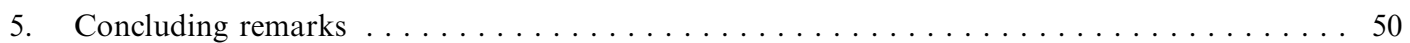

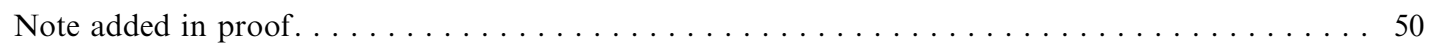

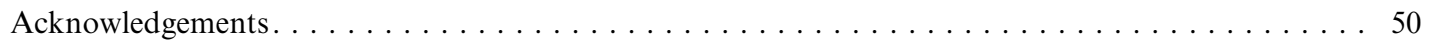

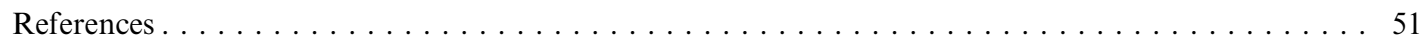

\section{Introduction}

The rush over the last decade to elucidate the neuroprotective effects of estrogen in disease or injury of the nervous system was precipitated by a series of findings which forced recognition of the potential impact of gonadal steroid hormones in disturbances of the nervous system. Key among these findings was the clear statistical bias toward either men or women in the incidence and recovery from neurological damage and mental disorders. Additionally, new tools were developed which allowed the mapping of estrogen receptors outside of the brain regions responsible for reproduction. Collectively, the evidence has led to a growing appreciation that the positive impact of estrogen on neurite outgrowth and neuronal survival in the hypothalamus might have more generalized applicability than was previously widely recognized.

Until the late seventies and early eighties, soon after morphological sex differences in the brain were first recognized in birds and mammals, the possible effects of estrogen on areas of the nervous system outside of those regions specifically involved in reproduction were often either unrecognized or disregarded as being irrelevant. Basic studies in neuroscience typically used mixed sex groups until it was appreciated that this induced a high degree of variability into the results of specific experiments. After that time, most researchers elected to use exclusively males for their studies, because they considered that experimental designs which took into account female cyclicity were too cumbersome to attempt, unless, of course, the subject of study was a specific aspect of female physiology or behavior. Societal issues that allowed disregard for disorders more prevalent in women, beliefs that humans are less susceptible to hormonal influences than other species, as well as extensive arguments within the medical community for biological vs cultural causation in psychiatric disturbances, may all have played a role in the traditional lack of appreciation of hormones as a possible positive influence in neurological and mental disorders. Potentially important hormone-dependent 
sex differences in specific disorders and in responses to therapeutic interventions were thus largely ignored. Although still controversial in some arenas, the idea that estrogen and other gonadal hormones may play a role in neuroprotection has gained general acceptance and is the subject of ever increasing investigation. A potential complication, but ultimate benefit, in examining the therapeutic role of estrogen in neuroprotection comes from the development of selective estrogen receptor modulators (SERMS) that target one estrogen sensitive tissue over another; the specific actions of SERMS in the nervous system will need to be evaluated, but SERMS may ultimately be useful in targeting neuroprotective actions of estrogen analogs, while not activating neuroendocrine functions.

Although epidemiological and basic science studies point to estrogen as an important factor in neuroprotection, proving such a role in clinical studies is not simple, for several important biological reasons. The functions of estrogen are intimately associated with those of progesterone and androgen, making it difficult to consider each independently with respect to neuroprotection. Estrogen regulates expression of both progestin (Thornton et al., 1986; Warembourg et al., 1986; Blaustein et al., 1988; DonCarlos et al., 1989; Bethea et al., 1992) and androgen (Handa et al., 1986, 1996; McAbee and DonCarlos, 1999a, 1999b) intracellular receptors, so that biologically relevant effects of progestin and androgen may depend on prior exposure to estrogen. Furthermore, testosterone is a precursor for estrogen synthesis, and the enzyme responsible for this conversion, aromatase, is expressed in the brain (Naftolin, 1994; Lephart, 1996; Celotti et al., 1997; Balthazart and Ball, 1998; Hutchison et al., 1999). During development, steroid hormone exposure may permanently alter the susceptibility to specific neurodegenerative diseases or alter recovery of function from traumatic episodes so that estrogen may have different effects in females and males due to differential sensitivity to the hormone. Genetic risk for certain diseases may be greater in males when genes on the $\mathrm{X}$ chromosome have an impact on the disease. Finally, because estrogen lowers cholesterol and alters immune function, the role of estrogen in neuroprotection may be indirect, through actions on other organs which then impinge upon the health of the brain.

A final introductory comment is that the term neuroprotection refers not to a single phenomenon but rather encompasses a spectrum of independent processes. Estrogen directly promotes cell survival, promotes synaptic plasticity, and prevents axonal and dendritic pruning. Estrogen can also prevent malfunction of neurons by altering levels of neurotransmitters, neurotransmitter receptors, and second messengers. This regulation of neurotransmitter function can then, secondarily, promote cell survival and neurite branch- ing. Thus, the protective effects of estrogen are multifaceted (Fig. 1). In this review, the primary, though not exclusive, focus is on the role of estrogen in cell survival.

\section{Neuroprotective effects of estrogen}

\subsection{Clinical studies}

Estrogen has been associated with a decreased risk, delayed onset and progression, or enhanced recovery from numerous traumatic or chronic neurological and mental diseases, some of which are discussed below. These span many different types of disease and trauma, ages, and hormonal status, and can be variously classified as dysfunction due to abnormal development (dyslexia, autism), abnormal neurotransmitter systems (depression; anorexia/bulimia), disorders caused by trauma (stroke, epilepsy, head injury), or disorders caused by abnormal immune (multiple sclerosis) or cardiovascular (stroke, head injury) function. The etiology of some disorders that are slowed or alleviated by estrogen is unknown (Alzheimer's disease, Parkinson's disease, sleep disorders). Some of these disorders are sexually differentiated in children, suggesting an effect of steroid hormones during development. Others present at times of altered hormonal status such as puberty, pregnancy or menopause, or increase with age. In the various sections below, selected examples of disorders and diseases for which there has been a preponderance of discussion or data suggesting a sex difference or estrogenic component in protection are discussed. The specific cellular mechanisms involved in estrogen dependent neuroprotection are discussed in later sections.

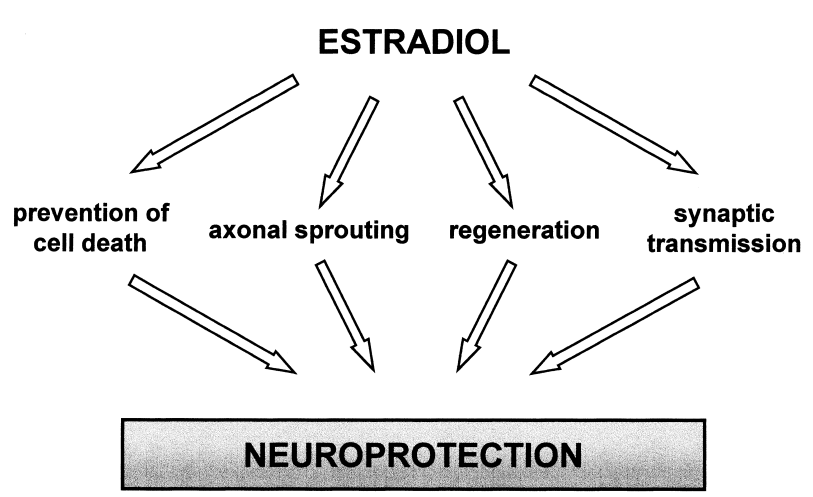

Fig. 1. Mechanisms that may be involved in neuroprotection by estradiol. The hormone may directly affect cell survival or prevent cell death by acting on cell death cascades. In addition, estradiol may promote cell survival by the induction of axonal sprouting of injured axons, by augmenting regeneration of damaged neural connections and by promoting synaptic transmission. 


\subsubsection{Stroke}

Stroke is a leading cause of mortality and morbidity in the population over middle age (reviewed in Paganini-Hill, 1995). Estrogen is thought to protect against stroke in humans, but whether this occurs throughout life, and the precise mechanisms estrogen might use to provide protection, are unclear. Men and women do not differ with respect to the primary risk factors for stroke, which are age and high blood pressure. Men and women do differ, however, with respect to the incidence of stroke, with premenopausal women having fewer strokes and different types of strokes than observed in age matched men; after menopause, the incidence of stroke increases in women compared to age matched premenopausal women. Most strokes $(80 \%)$ are due to cerebral infarct, the type of stroke most common in men. Subarachnoid hemorrhages are less common, but occur with higher frequency in women than in men (Kertesz and Benke, 1989; Paganini-Hill, 1995). In part, these differences appear to be due to the effects of endogenous estrogen on lowering of cholesterol levels and on vascular endothelium, protective effects that are lost in postmenopausal women. Differences in the inflammatory response may also contribute to the sex differences in response to infarct (Li et al., 1994) The observations from epidemiological studies that moderate exposure to exogenous estrogen may decrease the risk of stroke (discussed below), together with the finding that tamoxifen (an estrogen receptor antagonist) treatment confers increased risk for stroke in women (Gail et al., 1999) lend credence to the idea that estrogen plays a protective role in cerebrovascular disease. However, pregnancy and childbirth are associated with an increased risk of stroke. The National Institute for Neurologic Disorders and Stroke (1999) reported that the risk of ischemic stroke is nine times higher and hemorrhagic stroke 28 times higher during the first 6 weeks of postmartum, but the cause is not known.

High dose oral contraceptives, such as the preparations used before the 1980s, were associated with increased risk for stroke in premenopausal women, but the preparations now in use contain less estrogen, and are not associated with any increased risk for either ischemic or hemorrhagic stroke (Petitti et al., 1996, 1998; Chang et al., 1996). Paganini-Hill (1995) reviewed epidemiological studies that assessed the impact of estrogen replacement therapy on the relative risk for stroke. Many of the reports are conflicting; some have not demonstrated any effect of postmenopausal hormone use on stroke risk (eg, Petitti et al., 1998). However, the majority of studies have shown that continued use of estrogen, and to a lesser extent, former use of estrogen, reduces the risk of stroke by an average of $50 \%$ (e.g. Paganini-Hill et al., 1988; Falkeborn et al., 1993; Longstreth et al., 1994). Simi- larly, at least one estrogen receptor antagonist, tamoxifen, increases the risk of stroke (Gail et al., 1999). A magnetic resonance imaging and neuropsychiatric study found a lower incidence of asymptomatic ischemic brain damage in postmenopausal women taking estrogen compared with those who did not, but no association between the extent of white matter damage and cognitive test results (Schmidt et al., 1996). Since risk appears to depend on the type and amount of estrogen used, it is clear that clinical trials to determine the precise consequences of endogenous and exogenous steroid exposure in conferring the risk of stroke will need to be carefully designed. The potential negative influences of estrogen or estrogen receptor antagonists may restrict the use of estrogen as a preventative measure for stroke to a particular cohort of women.

Earlier studies have reported that the retention of verbal abilities is better in female stroke victims than in male stroke victims (reviewed in Kertesz and Benke, 1989), and that women experience a better recovery from aphasia than do men (Pizzamiglio et al., 1985), possibly due to differences in laterality or initial verbal fluency. Subsequent studies have altered this view: although the incidence of infarct may be higher in men than in women, among stroke patients with similar lesion size and location, no clear-cut sex differences exist in the frequency of aphasia (Kertesz and Sheppard, 1981; Kertesz and Benke, 1989; Hier et al., 1994), or prognosis for recovery of verbal fluency (Sarno et al., 1985; Schehter et al., 1985; Pedersen et al., 1995). On other measures, such as contralateral spatial neglect, men fare better than women when the right hemisphere is damaged (McGlone et al., 1997). Nevertheless, since basic science discoveries have pointed to the involvement of circulating and exogenous estrogen levels in the size of the lesion and recovery from experimentally induced stroke, estrogen may exert direct neuroprotective effects that limit damage to neurons following ischemia episodes in humans as well (see Section 2.2.2).

\subsubsection{Alzheimer's disease}

Alzheimer's disease afflicts more women than men, has an earlier onset in women, and progresses more rapidly in women. Many epidemiological studies have pointed to the protective role of estrogen in Alzheimer's disease. One extensive clinical study assessing the protective role of estrogen in Alzheimer's disease was conducted by Paganini-Hill and Henderson (1996). This study was based on postmortem follow-up reports of almost 4000 women who had answered a health survey that was administered, on average, 5 years before death. They found an inverse relationship between estrogen use and Alzheimer's disease; the risk of Alzheimer's disease decreased with increasing dose and duration of estrogen replacement therapy. Exogenous 
estrogen treatment appears to be the key, because there was no relationship between Alzheimer's disease and age at menarche or age at the last menstrual period, although higher body weight, and therefore presumably higher levels of estrogen due to formation in adipose tissue, conferred some decreased risk for Alzheimer's disease. Results of many other epidemiological studies are in agreement in demonstrating an inverse relationship between estrogen use and Alzheimer's disease (e.g. Tang et al., 1996; Yaffe et al., 1998; Costa et al., 1999; Slooter et al., 1999; Waring et al., 1999), but most discuss the methodological difficulties inherent in conducting and controlling large scale, survey based, studies and call for double blind analyses to be performed.

One of the earliest clinical trials assessing the potential impact of estrogen on Alzheimer's disease was a small pilot study of seven women who had been diagnosed with senile dementia of the Alzheimer's type (Fillit et al., 1986). Low-dose estrogen therapy modestly improved cognitive function and mood in some of the women. The large prospective study of Henderson, Paganini-Hill and collaborators (Henderson et al., 1994) also showed that estrogen not only protects against the onset of Alzheimer's disease, but also helps to maintain the cognitive function of those women who already have Alzheimer's disease. The cognitive function of women with Alzheimer's disease who had received estrogen replacement therapy was well below non-demented control subjects, but better than the cognitive function of those Alzheimer's disease patients not taking estrogen. Subsequent case-control (Resnick et al., 1998) and retrospective (Costa et al., 1999) studies have confirmed that estrogen protects postmenopausal women from cognitive deterioration.

Double-blind studies will be the key to confirming a clinically significant role for estrogen in protection from Alzheimer's disease; the number of such studies is still low, and study sizes are small, but the findings support the use of estrogen to delay the onset of Alzheimer's disease and slow its progression. In one double-blind study of 12 women with mild to moderate Alzheimer's disease, estrogen $(0.05 \mathrm{mg} /$ day of $17 \beta$ estradiol, delivered via a skin patch), improved attention and verbal memory within the first week of treatment, but the effects were temporary, and diminished once estrogen treatment was stopped (Asthana et al., 1999). It is of interest that there was a trend to an inverse relationship between plasma levels of both IGF-I and IGF-binding protein 3 and verbal memory, given that IGF-I is generally neuroprotective (see "Neurotrophins", p. 45). Estrogen increased activation of cortical regions involved in verbal memory tasks during storage and retrieval of verbal material, without altering verbal or nonverbal performance, in postmenopausal women given estrogen treatment $(1.25 \mathrm{mg} /$ day, oral dose, 21 days, double-blind) and assessed using functional magnetic resonance imaging.

The potential cellular mechanisms that may underlie estrogen's neuroprotective actions are discussed in Section 3, but a specific series of genetic findings are worth mentioning here with respect to estrogen and Alzheimer's disease susceptibility. First, there is an apparent interaction between estrogen receptor, apolipoprotein $\mathrm{E}$ (ApoE) and deposition of amyloid in the neuritic plaques that are one of the neuropathological hallmarks of Alzheimer's disease (Fig. 2). Some background regarding the role of ApoE and beta amyloid is necessary here: ApoE is produced by astrocytes and microglia (see also Section 3.2.3.1), is important to membrane repair and synaptic plasticity (Teter et al., 1999 and see Bales et al., 1999 for a discussion) and is thought to reduce clearance of amyloid beta (Bales et al., 1999). Amyloid beta is a component of neuritic plaques that may itself be neurotoxic. The expression of ApoE may in fact be necessary for production of the abnormal amyloid deposits, since transgenic mice that overexpress beta amyloid precursor protein and are also $\mathrm{ApoE}(-/-)$ produce no amyloid deposits, whereas amyloid deposits are frequent in $\operatorname{ApoE}(+/-)$ and $\operatorname{ApoE}(+/+)$ mice (Bales et al., 1999). There are three allelic variants encoding three protein isoforms of ApoE. Of these, the highest risk of Alzheimer's disease, particularly the late-onset form, is found in individuals who are homozygous for the ApoE epsilon 4 allelle on chromosome 19 (Henderson et al., 1995). Estrogen may normally ward off damage due to ApoE induced abnormalities in amyloid precursor protein processing, as estrogen has been shown to reduce the production of the neurotoxic, insoluble beta amyloid (Jaffe et al., 1994; Chang et al., 1997; Xu et al., 1998a, 1998b). Exogenous estrogen reduces the risk of Alzhei-

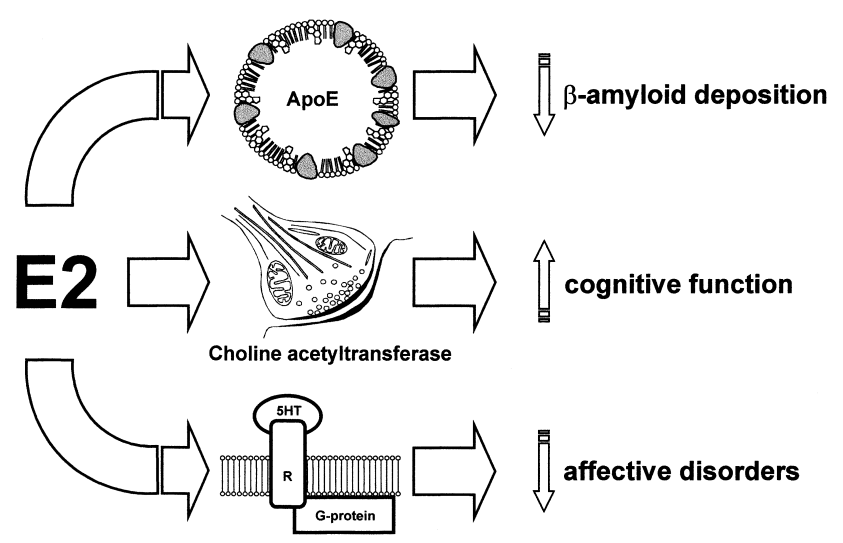

Fig. 2. Possible actions of estradiol in Alzheimer's disease. Estradiol may affect beta-amyloid deposition by the regulation of beta-amyloid metabolism and ApoE expression. The hormone may increase cognitive function by enhancing cholinergic neurotransmission. Finally, estradiol may influence affective disorders associated with Alzheimer's disease by acting on serotonin receptor signaling. 
mer's disease in individuals who are either homozygous or heterozygous for the ApoE epsilon 4 allele (Tang et al., 1996).

Although it has been hypothesized that estrogen protects against beta amyloid deposition via its antioxidant properties (Mattson et al., 1997; Bonnefont et al., 1998), nuclear receptor mediated mechanisms also appear to be involved in estrogenic neuroprotection in Alzheimer's disease because estrogen receptor polymorphisms, as identified by restriction fragment length polymorphism analysis as $\mathrm{P}$ or $\mathrm{p}$ alleles (PvuII- RFLP) or $\mathrm{X}$ and $\mathrm{x}$ (Xba I-RFLP) are also associated with dementia. The frequency of the $\mathrm{P}$ and $\mathrm{X}$ alleles for estrogen receptor were found to be higher in Alzheimer's disease patients and Parkinson's disease patients with dementia, but not in Parkinson's patients without dementia or in control subjects (Isoe-Wada et al., 1999). One of the most important recent findings, potentially of enormous predictive value, is a genetic interaction between polymorphisms for both the estrogen receptor and ApoE genes (Brandi et al., 1999; Isoe-Wada et al., 1999). Brandi et al. (1999) calculated that the frequency of late-onset of Alzheimer's disease was seven fold greater in those individuals that are homozygous for ApoE epsilon 4 and ER- $\alpha$ PPXX.

Another important molecular association for estrogen in Alzheimer's disease involves expression of choline acetyltransferase (Fig. 2). Cholinergic neurons in the basal forebrain degenerate in Alzheimer's disease patients (Whitehouse et al., 1981). Correlative studies of choline acetyltransferase activity in biopsy specimens results of neuropsychological tests have demonstrated that the loss of choline acetyltranferase activity is correlated with the loss of cognitive function (Baskin et al., 1999). Estrogen upregulates choline acetyltransferase in the rat brain (Luine, 1985) although it is not known whether this occurs in humans, nor is the potential mechanism involved clear, since immunocytochemical studies of the primate basal forebrain have found that estrogen receptor alpha immunopositive cells are rare and do not contain cholinergic markers (Blurton-Jones et al., 1999).

Other neurotransmitter systems are also implicated in the etiology of Alzheimer's disease, and estrogen may be protective through its effects on these systems (Fig. 2). For example, estrogen normalizes neuroendocrine responses to a serotonergic agonist in postmenopausal women (Halbreich et al., 1995) and may decrease affective disorders via estrogen induced decreases in the $G$ proteins that couple serotonin receptors to intracellular signaling molecules (Raap et al., 2000) or via alterations in serotonin transporter expression (McQueen et al., 1997). Depression is one of the early symptoms of Alzheimer's disease; abnormalities of serotonergic function have been proposed to be causal in both disorders (e.g. Meltzer et al., 1998).
In conclusion, the etiology of Alzheimer's disease is clearly multifactorial, but for many of the factors, estrogen may provide protective value, and estrogen receptor malfunction may increase risk. Considerable support is therefore available for the use of estrogen replacement therapy to decrease vulnerability to Alzheimer's disease, and in those individuals who are already diagnosed with Alzheimer's disease, to maintain cognitive function (see note added in proof).

\subsubsection{Schizophrenia}

The overall lifetime risk for schizophrenia is not different between men and women (reviewed in Lindamer et al., 1997; Seeman, 1997; Canuso et al., 1998; Hafner et al., 1998). However, the age of onset, the severity of symptoms, and the type of symptoms are different in men and women and point to a protective role for estrogen in schizophrenia. Schizophrenia generally occurs slightly later in women and, until menopause, has a less severe course in women than in men. Moreover, although the peak age of onset for schizophrenia is generally late adolescence to early adulthood in both men and women, a second cohort of women develops schizophrenia at the onset of menopause, as estrogen levels begin to fluctuate and decline (Lindamer et al., 1999). Numerous correlational studies show that the severity of psychiatric disturbance decreases with increasing estradiol levels during the menstrual cycle and during pregnancy. Preliminary results from limited clinical trials with hormone replacement therapy provide further evidence that estrogen is protective, and decreases a specific subset of schizoid symptoms.

Abnormalities of brain maturation may lead to structural abnormalities that underlie schizophrenia, and sex hormone exposure during development may therefore contribute to the sex differences in schizophrenia (Gruzelier, 1994; Nopoulos et al., 1997). There are conflicting results as to whether sex differences actually exist in the brain structural abnormalities associated with schizophrenia as would be expected if sex hormone exposure during development contributes to the greater vulnerability of the male brain. Two carefully controlled, and similar magnetic resonance imaging (MRI) studies demonstrate these conflicting results. In the first, male and female hospitalized schizophrenics had similar decreases in cortical gray matter and similar ventricular enlargement compared with healthy, sex-matched controls (Lauriello et al., 1997). In the second study, the cortical gray matter was decreased and the ventricles were enlarged to a greater extent in male schizophrenics compared with female schizophrenics when each group was compared to its healthy sex and age matched control group (Nopoulos et al., 1997); these investigators emphasized that the sex difference is one of severity of the structural 
abnormality, rather than pattern. Different conclusions have also been reached regarding sex differences in the extent of cognitive impairment in schizophrenic patients, with some studies concluding that male patients are more impaired than female patients (Goldstein et al., 1998) and others concluding that any sex differences in the degree of impairment are minimal (Hoff et al., 1998).

Modulation of dopaminergic function may underlie the protective effects of estrogen. The dose of neuroleptic drugs required to treat women with schizophrenia is lower than that for men, at least at the younger ages (reviewed in Di Paolo, 1994 and in Canuso et al., 1998). Estrogen may act essentially as an endogenous neuroleptic since estrogen seems to enhance the actions of dopamine antagonists in animal models (Hafner et al., 1991). Preliminary results suggest that dopamine receptor affinity is lower in some brain regions in women than in men (Pohjalainen et al., 1998).

In addition to circulating estrogen, a genetic component may also contribute to sex differences in the onset and course of schizophrenia (Hafner et al., 1998). A case has been made by Gruzelier (1994) that sex chromosomes may contribute to the observed differences in schizophrenia in men and women, particularly those sex differences in the symptoms thought to arise from abnormalities of brain lateralization. Structural abnormalities in the temporoparietal region and cognitive deficits have been observed in women with Turner's syndrome, who have either a karyotype $\mathrm{XO}$ or a mosaic XO karyotype. The hormonal deficiencies in both Turner's syndrome groups are similar, but the cognitive and structural impairments of the mosaic XO women are less severe than those of full XO women. The structural abnormalities and patterns of cognitive asymmetry observed in Turner women and in Kleinefelter's (XXY) men are consistent with some of the abnormalities observed in schizophrenia. Trinucleotide repeats confer some genetic risk for schizophrenia, particularly the childhood onset form of the disease, and are more common in males (Burgess et al., 1998).

\subsection{Experimental studies}

\subsubsection{In vitro evidence}

For many years, it has been known that estradiol is a factor that promotes viability and survival of neurons in primary neuronal cultures. Estradiol is one of the components that is added to serum-free defined culture media for neuronal cultures (Faivre-Bauman et al., 1981). Addition of $17 \beta$-estradiol to defined culture media increases the viability, survival and differentiation of primary cultures from different neuronal populations, including hypothalamic neurons (Chowen et al., 1992; Dueñas et al., 1996), amygdala neurons (Arimatsu and Hatanaka, 1986), neocortical neurons (Brinton et al., 1997) or hippocampal neurons (Sudo et al., 1997). In addition, in vitro neuroprotective effects of $17 \beta$-estradiol from cell death induced by a variety of stressors are well documented (Table 1). The hormone increases survival of cultured dorsal root ganglion neurons deprived of nerve growth factor (Patrone et al., 1999), primary mesencephalic cultures exposed to glutamate, superoxide anions or hydrogen peroxide (Sawada et al., 1998) and hippocampal cultures exposed to NMDA (Weaver et al., 1997). Many studies using primary cortical cultures have shown that estradiol prevents neuronal death induced by different stimuli such as iron (Vedder et al., 1999) glutamate toxicity (Singer et al., 1996b; Zaulyanov et al., 1999), AMPA toxicity (Zaulyanov et al., 1999), the pro-oxidant hemoglobin (Regan and Guo, 1997), anoxia (Zaulyanov et al., 1999), cytochrome oxidase inhibitor sodium azide, kainate or NMDA (Regan and Guo, 1997). Other studies have used neuronal cell lines to demonstrate the neuroprotective effects of estradiol. For instance, $17 \beta$ estradiol protects NT2 neurons, PC12 cells and mouse neuroblastoma (Neuro 2a) cells from $\mathrm{H}_{2} \mathrm{O}_{2}$ or glutamate induced cell death (Singer et al., 1998; Bonnefont et al., 1998), SK-N-SH human neuroblastoma cells from serum deprivation (Green et al., 1997), hippocampal HT 22 cells from lipid peroxidation (Vedder et al., 1999) and B 103 cells (MookJung et al., 1997), PC12 cells and Neuro 2a cells (Bonnefont et al., 1998) from neurotoxic effects of beta amyloid. This long, but not exhaustive, list of studies reveals that the neuroprotective effects of estradiol have recently received considerable attention. These in vitro studies have provided important insights into the possible mechanisms involved in the in vivo neuroprotective effects of estrogen that will be discussed below.

Table 1

Summary of experimental lesion models in which estradiol has been shown to be neuroprotective

Estradiol neuroprotection in experimental lesion models

\begin{tabular}{ll}
\hline In vitro (Section 2.2.1) & In vivo (Section 2.2.2) \\
\hline Anoxia & Ischemia \\
Serum deprivation & Neurotoxins \\
Oxidative stress & MPTP \\
$\quad$ Hemoglobin & 6-Hydroxydopamine kainic acid \\
Iron & Axotomy \\
$\quad$ Hydrogen peroxyde & \\
$\quad$ Sodium azide & \\
Excitatory aminoacids & \\
$\quad$ Glutamate & \\
Kainate & \\
$\quad$ NMDA & \\
$\beta$-Amyloid protein & \\
\hline
\end{tabular}




\subsubsection{In vivo evidence}

In addition to the extensive evidence for neuroprotective effects of estradiol in vitro, there is now abundant evidence for neuroprotection by the hormone in different experimental models in vivo (Table 1). In agreement with clinical findings, several animal studies have shown that estrogen improves memory performance in females. Estrogen replacement improves working memory in ovariectomized rats (Simpkins et al., 1997a; Bimonte and Denenberg, 1999; Fader et al., 1999) but does not affect reference memory performance (Fader et al., 1999). In ovariectomized mice, tonic estrogen replacement therapy improves two different types of memory processes that depend on striatal and hippocampal memory systems (Rissanen et al., 1999). Estrogen treatment has been shown to improve memory performance in male rodents as well. Estradiol treatment of male rats partially compensates for the learning deficits and deterioration of memory induced by the intracerebroventricular administration of streptozotocin (Lannert et al., 1998). These findings suggest that estrogen may have a general enhancing effect on neural activity and may be involved in the normal maintenance of neural function. Therefore, the decline in estrogen levels that occurs with age may be the cause of the increased rate of age-related cognitive impairments in female rodents compared to males (Markowska, 1999; Frick et al., 2000). The decrease in estrogen levels with age in females may increase the risk of neurodegenerative disorders since the hormone has been shown to protect neurons in vivo from different lesion paradigms.

Experimental forebrain ischemia has been one of the models used to test the neuroprotective effect of estradiol in vivo. The protective effects of estrogen in this model have been documented in rats (Simpkins et al., 1997b; Dubal et al., 1998; Pelligrino et al., 1998; Zhang et al., 1998; Wang et al., 1999; Rusa et al., 1999), mice (Culmsee et al., 1999) and gerbils (Sudo et al., 1997; Chen et al., 1998). Simpkins et al. (1997b) have shown that pretreatment with $17 \beta$-estradiol reduces animal mortality and ischemic area in ovariectomized rats after middle cerebral artery occlusion. Interestingly, the isomer $17 \alpha$ was able to reduce mortality and to reduce the ischemic area as well. Both systemic and intracerebral administration of $17 \beta$-estradiol were protective in this model. In the study of Dubal et al. (1998), systemic estradiol pretreatment significantly reduced overall infarct volume compared with oil injected controls. Sudo et al. (1997) tested the effect of estradiol administered into the lateral cerebral ventricle. These authors have shown that $17 \beta$-estradiol infused into the lateral cerebral ventricle prevents ischemia-induced learning disability and neuronal loss at early stages after transient forebrain ischemia in gerbils (Sudo et al., 1997). Chen et al. (1998) have also found a neuroprotective effect of $17 \beta$-estradiol on CA1 hippocampal cells after ischemia in gerbils. Furthermore, 17 $\beta$-estradiol decreases the expression of betaamyloid precursor protein mRNA following focal ischemia in ovariectomized female rats (Shi et al., 1998).

Another experimental model of great interest is injury of the nigrostriatal system. Estrogen has neuroprotective properties against 1-methyl-4-phenyl-1,2,3,6tetrahydropyridine (MPTP)-induced neurotoxicity in the nigrostriatal dopaminergic system. Estradiol treatment prevents reductions in dopamine concentrations in the striatum of ovariectomized mice (Dluzen et al., 1996a, 1996b; Dluzen, 1997, 2000; Callier et al., 2000). Furthermore, 17 $\beta$-estradiol reduces the dyskinetic effect of MPTP in cynomolgus monkeys, while $17 \alpha$ estradiol is ineffective (Gomez-Mancilla and Bedard, 1992). Basal forebrain cholinergic neurons may also be protected by estradiol, since Rabbani et al. (1997) found that administration of $17 \beta$ estradiol to ovariectomized rats attenuated the decrease of choline acetyltransferase immunoreactive neurons in the medial septum after fimbria lesion-induced degeneration.

The neuroprotective effect of estradiol on the hilus of the dentate gyrus has been investigated after systemic administration of kainic acid, a widely used experimental model of epilepsy and neurodegeneration. Kainic acid treatment results in the appearance of chronic, spontaneous, recurrent seizures and neurodegenerative changes in the dentate gyrus, including loss of somatostatinergic interneurons in the hilus. Systemic administration of a low dose of kainic acid $(7 \mathrm{mg} / \mathrm{kg}$ b.w.) results in mild behavioral symptoms and a loss of no more than $25-40 \%$ of Nissl-stained hilar neurons. Administration of $17 \beta$-estradiol to ovariectomized rats is able to prevent this partial hilar neuronal loss (Azcoitia et al., 1998). Of critical importance with regard to the normal neuroprotective effects of estrogen, the effect of kainic acid on hilar neurons in intact female rats is different depending on the day of the estrous cycle on which the neurotoxin is injected. No significant neuronal loss is observed when kainic acid is injected on the morning of estrus. In contrast, there is a significant loss of hilar neurons when kainic acid is injected in the morning of proestrus as well as when it is injected into ovariectomized rats (Azcoitia et al., 1999a). These findings demonstrate that the natural fluctuation of ovarian hormones during the estrous cycle may influence the vulnerability of hilar neurons to excitotoxicity.

The possible neuroprotective effect of estrogen has been tested in male rats as well. Estradiol treatment results in an increase in the rate of regeneration of axotomized facial motoneurons of male hamsters, an effect also induced by testosterone and by the non aromatizable androgen dihydrotestosterone (Tanzer and 
Jones, 1997). Toung et al. (1998) have found that either acute or chronic administration of $17 \beta$-estradiol protects the male rat brain after experimental stroke using $2 \mathrm{~h}$ of reversible middle cerebral artery occlusion. Cortical and caudate infarct volumes are reduced by acute and chronic hormonal treatments. Toung et al. (1998) and Kujawa and Jones (1991) also studied the effect of castration on neural response to injury. Castration did not alter ischemic outcome whereas estrogen replacement reduced infarct volume in castrated animals. Similarly, the rate of regeneration following facial nerve axotomy was not different in intact vs. castrated male hamsters (Kujawa and Jones, 1991). Both studies suggested that circulating testosterone levels are insufficient to supply prohormone to provide neuroprotective levels of estrogen in vivo. Estrogen also has neuroprotective properties against MPTPinduced neurotoxicity in the nigrostriatal dopaminergic system of castrated males, preventing reductions in corpus striatum dopamine concentrations (Dluzen et al., 1996a, 1996b). However, the interpretation of the neuroprotective effects of estrogen in male animals is complicated by the possible influence of androgens.

Clinical data show that women recover better than men after traumatic brain injury (Groswasser et al., 1998). In agreement with this observation, and with those commented on in Section 2.1.1 in several experimental neural lesion models male animals are more vulnerable than female animals. For instance, female rats have better stroke outcomes after vascular occlusion than males (Li et al., 1996; Alkayed et al., 1998; Zhang et al., 1998), while male rats show stronger memory deficits after entorhinal cortex lesions than females (Roof et al., 1993a). Sex differences have been also observed in striatal dopaminergic neurotoxicity in mice (Miller et al., 1998). Two neurotoxicants tested, MPTP and methamphetamine (METH), resulted in a greater dopamine depletion in males than in females (Yu and Wagner, 1994; Miller et al., 1998). However, in a study in which the susceptibility of the cholinergic septo-hippocampal pathway to the neurotoxic effect of ethylcholine aziridinium (AF64A) was investigated in the rat, Hortnagl et al. (1993) found that adult female rats in general, and particularly females on proestrus, were more susceptible to the neurotoxic action of submaximal doses of AF64A than age-matched male rats.

Sex differences in outcome after different forms of brain lesions may be due in part to estrogen, progesterone or testosterone. Neuroprotective effects of progesterone will not be covered in depth in this review, except to mention that several studies have shown that progesterone may reduce cerebral damage after different forms of insults (Stein and Fulop, 1998). For instance, progesterone facilitates cognitive recovery, reduces secondary neuronal loss and protects against lipid peroxidation following traumatic brain injury in rats (Roof et al., 1993b, 1994, 1997; Asbury et al., 1998) and reduces neuronal loss in the cat hippocampus after acute cerebral ischemia (GonzalezVidal et al., 1998). Sex differences in the response to brain injury may also be the consequence of a damaging effect of testosterone. While testosterone is a survival factor for axotomized motoneurons and promotes motor axon regeneration (Yu, 1989; Jones, 1993; Kujawa et al., 1993; Perez and Kelly, 1996, 1997; Kinderman et al., 1998), the hormone may have a negative effect for other injured neuronal populations. For instance, testosterone increases the lesion size induced by middle cerebral artery occlusion in castrated male rats, while estradiol treatment reduces the ischemic area (Hawk et al., 1998). Nishino et al. (1998) have used systemic intoxication with 3-nitropropionic acid, a succinate dehydrogenase inhibitor, to induce selective histological lesions in the striatum. These lesions are associated with motor symptoms and are highly sex-dependent. Males are more susceptible than females. Gonadectomy has little effect on males but enhances the vulnerability of females to the substance. Furthermore, testosterone increases the vulnerability while estrogen replacement suppresses the vulnerability in ovariectomized rats (Nishino et al., 1998).

The deleterious effect of testosterone in some experimental models of brain injury may be secondary to its conversion to dihydrotestosterone and its action on androgen receptors. However, it is important to consider the possibility that the negative effect of testosterone may be the consequence of its conversion to estradiol by local aromatase activity. It is well known that high levels of estradiol may be neurotoxic for some hypothalamic neurons (Brawer et al., 1978; Desjardins et al., 1995), and the idea cannot be excluded that high local levels of estrogen may be neurotoxic for other neuronal populations as well. This would mean that high local levels of estrogen may be deleterious while low local levels of estrogen may provide neuroprotection. Therefore, it is important to determine the concentration of estradiol that may exert a neuroprotective effect in vivo.

Several studies have assessed whether the neuroprotective effects of estrogen in different lesion paradigms are dose-dependent. For example, the effect of estradiol in preventing ischemic damage is dose-dependent. When infused at a dose of $0.25 \mu \mathrm{g} /$ day, estradiol decreased ischemic damage in gerbils, whereas a dose of $1.25 \mu \mathrm{g} /$ day was ineffective and even increased mortality of experimental animals (Sudo et al., 1997). Different results have been obtained by Chen et al. (1998). According to these authors, high doses of $17 \beta$ estradiol improve the histological outcome after transient forebrain ischemia in hippocampal CA1 pyramidal cells of gerbils, whereas low doses of estradiol do not 
have any protective effect. In rats, chronic low-dose estradiol treatment $(0.1 \mathrm{mg} / \mathrm{kg}$ per day) has a beneficial effect on cortical cerebral blood flow during forebrain ischemia. However, the benefit is lost with a dose of $0.5 \mathrm{mg} / \mathrm{kg}$ per day or with higher doses (Pelligrino et al., 1998). Dubal et al. (1998) have found neuroprotective effects of low (10 pg/ml in plasma) and high (100 $\mathrm{pg} / \mathrm{ml}$ in plasma) estradiol levels in the rat cerebral cortex after ischemia. In another study, long term treatment with $17 \beta$-estradiol implants of $25 \mu \mathrm{g}$ (resulting in $20 \mathrm{pg} / \mathrm{ml}$ in plasma) reduces stroke injury in ovariectomized females while implants of $100 \mu \mathrm{g}$ (46 $\mathrm{pg} / \mathrm{ml}$ in plasma) do not (Rusa et al., 1999). These studies show some discrepancies concerning the optimal dose of estradiol needed to obtain a neuroprotective effect in vivo. This may be in part because different brain areas require different optimal hormone concentrations. The severity of the lesion and the route of administration may also be an important determinant in the hormone concentration required to counterbalance the damage. In spite of the discrepancies, most studies show a neuroprotective effect at low estradiol doses. This finding is relevant to the mechanism of action, as discussed below.

\section{Mechanisms of neuroprotection by estradiol}

\subsection{Peripheral versus local effects}

The possible neuroprotective mechanisms of estradiol may be divided into two basic groups: local and peripheral, local effects being those exerted directly in the nervous system and peripheral effects being those exerted in other tissues, such as the systemic regulation of metabolism and the cardiovascular system. Hormonal effects on the cardiovascular system may facilitate brain irrigation and therefore may protect neurons and glia from ischemia. Peripheral metabolic and cardiovascular effects of the hormone will not be considered in this review. Among the local effects, it is important to distinguish those mediated by the activation of estrogen receptors and those that are not dependent on the actions of estrogen receptors. Furthermore, the local effects of estradiol may be divided into those exerted on neurons and those exerted on glial cells or other cellular elements of the nervous system. These different local effects of estrogen will be considered in the following sections.

\subsection{Local effects}

\subsubsection{Mechanisms independent of the transcriptional activation by estrogen receptors}

Among the local hormonal effects, there is a strong line of evidence supporting mechanisms independent of estrogen receptor activation. Some in vitro studies have shown that high, non-physiological doses of estradiol are neuroprotective while low doses of estradiol, optimal to induce estrogen receptor-mediated gene transcription, are not. For instance, $133 \mathrm{nM} 17 \beta$ or $17 \alpha$-estradiol but not $1.3 \mathrm{nM} 17 \beta$-estradiol protect primary rat cortical neuronal cultures from anoxiareoxygenation, glutamate, or AMPA toxicity (Zaulyanov et al., 1999). Furthermore, protective effects of estradiol have been documented in neuronal cell lines lacking functional estrogen receptors or in the presence of estrogen receptor antagonists. Both $17 \alpha$ and $17 \beta$ estradiol provide protection of SK-N-SH human neuroblastoma cells from serum deprivation and the neuroprotective effect was only partially reversed by the estrogen receptor antagonist tamoxifen. This finding suggests that estrogen may have neuroprotective effects that are not mediated by estrogen receptor signaling (Green et al., 1997), although another possibility is that tamoxifen exerted partial agonist activity in these cells. A neuroprotective effect of estradiol independent of estrogen receptors has been demonstrated in the HT-22 murine neuronal cell line. $17 \beta$ estradiol and $17 \alpha$ estradiol protect HT-22 cells from beta-amyloid peptide toxicity, in spite of the fact that these cells lack functional estrogen receptors (Green et al., 1998).

Neuroprotection independent of estrogen receptors has been observed in primary neuronal cultures as well. The estrogen receptor antagonist, tamoxifen, does not interfere with the neuroprotective effects of $17 \beta$-estradiol against NMDA-induced neuronal death in rat hippocampal cultures (Weaver et al., 1997). Furthermore, neither estrogen receptor antagonists nor protein synthesis inhibitors block estrogen-induced protection against glutamate neurotoxicity in mesencephalic cultures (Sawada et al., 1998). In addition, estrogen receptor antagonists do not block the protective effects of estradiol against pro-oxidants in rodent and chick neuronal cultures (Behl et al., 1995, 1997; Regan and Guo, 1997; Culmsee et al., 1999; Moosmann and Behl, 1999).

One of the most popular views to explain the neuroprotective effects of the hormone is related to the endogenous antioxidant capacity of the estradiol molecule (Fig. 3). It is very well documented that estradiol has antioxidant properties and suppresses the oxidative stress in neurons and neuronal cell lines induced by hydrogen peroxide, superoxide anions and other pro-oxidants (Behl, 1999; Behl et al., 1995, 1997; Mattson et al., 1997; Bonnefont et al., 1998; Sawada et al., 1998; Behl and Holsboer, 1999; Calderon et al., 1999; Culmsee et al., 1999; Kruman et al., 1999; Moosmann and Behl, 1999; Behl and Manthey, 2000). Both $17 \alpha$ and $17 \beta$ estradiol have similar antioxidant effects (Behl et al., 1995, 1997; Calderon et al., 1999; Bonnefont et al., 1998). 
Supraphysiologic concentrations of estradiol have a clear antioxidant effect in vitro. For instance, 17 $\beta$ estradiol, $17 \alpha$-estradiol and some estradiol derivatives can prevent intracellular peroxide accumulation and degeneration of cultured neurons and clonal hippocampal cells. The antioxidant activity of estrogens is observed at very high concentrations $\left(10^{-5} \mathrm{M}\right)$, is dependent on the presence of the hydroxyl group in the $\mathrm{C} 3$ position on the $\mathrm{A}$ ring of the steroid molecule and is independent of an activation of the estrogen receptors (Behl et al., 1995, 1997; Culmsee et al., 1999; Moosmann and Behl, 1999; Behl and Manthey, 2000). A similar finding has been reported by Regan and Guo (1997), showing that $17 \beta$-estradiol at a dose of 10 $\mu \mathrm{M}$ results in a complete prevention of neuronal loss in murine cortical cultures due to prolonged exposure to the pro-oxidant hemoglobin. Most of this effect persisted despite concomitant treatment with the antiestrogen ICI 182, 780 or the protein synthesis inhibitor cycloheximide (Regan and Guo, 1997).

Lipid peroxidation of membrane and fatty acids represents an important endpoint of pro-oxidative cell damage. Keller et al. (1997) and Vedder et al. (1999) have used iron, one of the most powerful initiators and propagators of lipid peroxidation, to determine the role of estradiol on lipid peroxidation. These authors found that 17 $\beta$-estradiol decreases ironinduced lipid peroxidation in rat brain homogenates (Vedder et al., 1999), rat cortical synaptosomes (Keller et al., 1997), hippocampal HT 22 cells and primary neocortical cultures (Vedder et al., 1999). However, it is unlikely that this mechanism will be relevant clinically for the neuroprotective effects of estradiol, since

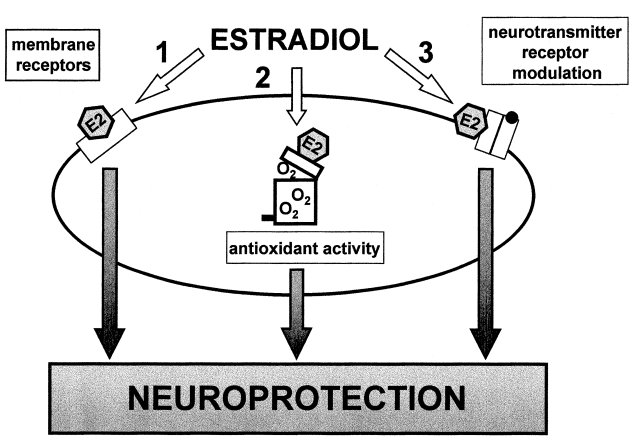

Fig. 3. Summary of mechanisms independent of the activation of nuclear estrogen receptors that may be involved in estrogen-induced neuroprotection. 1, Estrogen may act on unidentified membrane sites and activate membrane associated signaling cascades that result in neuroprotection. The membrane-associated signaling may involve modifications in protein phosphorylation and modifications in the levels of intracellular signals such as cAMP and calcium. Alternatively, membrane related signaling cascades may result from the interaction of estradiol with putative membrane estrogen receptors (see Fig. 4). 2, Estradiol may act as an antioxidant. 3, Estradiol may affect neurotransmitter receptors, such as glutamate receptors, and regulate ionotropic and metabotropic activity. very high concentrations of the hormone are necessary to reduce lipid peroxidation (Vedder et al., 1999).

In conclusion, it is clear that estradiol has antioxidant properties and may protect neurons from oxidative stress. However, these effects are observed with high supraphysiologic concentrations of the hormone and their relevance to the neuroprotective effects of estradiol in vivo is questionable, particularly in a clinical sense. It should be noted, however, that it is unknown what the local concentrations of the hormone may be in a focal injured area in the brain. The recent discovery that aromatase expression is induced de novo in reactive astrocytes in injured brain areas (Garcia-Segura et al., 1999a) opens the possibility that injury induced increases in aromatase synthesis, and therefore increased local estrogen formation, may result in high local estrogen levels in the proximity of damaged neurons.

In addition to anti-oxidant effects, estradiol may use other possible neuroprotective mechanisms that are independent of nuclear estrogen receptor activation (Fig. 3). Estradiol may interact with estrogen binding sites in the plasma membrane (Ramirez and Zheng, 1996) and may have many different rapid effects on neuronal excitability (Moss and $\mathrm{Gu}, 1999$ ) and neuronal transmission (Bicknell, 1998). In rat hippocampal cultures estradiol may protect neurons from excitotoxicity by having direct membrane actions (Weaver et al., 1997). The neuroprotective effect of $17 \beta$-estradiol is dose-dependent, with an EC50 of about $7 \mu \mathrm{M}$. In this model, $17 \alpha$-estradiol does not reduce NMDA-induced neuronal death, indicating that the neuroprotective effect of estradiol is stereospecific. However, tamoxifen does not interfere with the neuroprotective effect, suggesting that estrogen receptors are not required for neuroprotection (Weaver et al., 1997). Since both $\alpha$ and $\beta$-estradiol should have similar abilities to scavenge free radicals and since $17 \beta$-estradiol rapidly and reversibly inhibits the NMDA-induced current of cultured neurons, Weaver et al. (1997) conclude that the neuroprotective effect of the hormone may be a consequence of direct inhibition of NMDA receptor function. The neuroprotective effects of the hormone may be in part related to the modulation of neurotransmitters. For instance, estradiol may protect the nigrostriatal system by the regulation of dopamine release and via the inhibition of dopamine uptake by decreasing the affinity of the transporter for dopamine (Disshon and Dluzen, 1997; Disshon et al., 1998; Dluzen, 2000). Neuroprotective effects that involve hormonal activation of intracellular signaling pathways via $G$ proteins (Moss and Gu, 1999; Raap et al., 2000), extracellularly regulated kinases (see Section 3.2.3.3), phosphorylation of the cAMP response element binding protein (Zhou et al., 1996; Murphy and Segal, 1997; Panickar et al., 1997; Watters and Dorsa, 1998; 
Walton and Dragunow, 2000), and alterations in intracellular calcium levels (Beyer and Raab, 1998; PozzoMiller et al., 1999) should still be explored in detail.

\subsubsection{Mechanisms mediated by the activation of estrogen receptors and gene transcription}

\subsubsection{Estrogen receptor mediated transcription in the} nervous system. Many, though not all, of the physiological effects of estrogen are mediated through binding to estrogen receptor (ER) proteins. Like other members of the steroid receptor superfamily, estrogen receptors are ligand-activated transcription factors that are expressed in specific regions within target areas of the nervous system and other estrogen-sensitive organs. Until 1996, it was thought that only one estrogen receptor existed, but in that year and the next, two surprising discoveries indicated the presence of more than one estrogen receptor and greatly stimulated the field of estrogen receptor research. The first surprise came from accumulated evidence that, contrary to expectations, disruption of the estrogen receptor gene in mice did not disrupt all estrogen dependent functions; in the estrogen receptor knock out mice, residual levels of estrogen binding were present in several brain region and estrogen induced expression of progesterone receptor, an estrogen-dependent gene (Shughrue et al., 1997a, 1997c). This research team concluded that, since the conventional ER had been disrupted, a variant form of ER might be present.

The second surprise discovery, also announced in the spring of 1996, was that a new estrogen receptor protein had been cloned (Kuiper et al., 1996). With this finding, the conventionally defined ER was designated estrogen receptor- $\alpha$ (ER- $\alpha)$, and the new one was named ER- $\beta$. ER- $\beta$ mRNA was rapidly identified in numerous tissues, including the adult rat brain where it was found in a distribution that overlaps that of ER- $\alpha$ in some regions, but in other regions is quite distinct, as discussed below. Multiple splice variants of ER- $\beta$ have been identified, adding another layer of complexity to estrogen signal transduction (Petersen et al., 1998; Hanstein et al., 1999). Of these splice variants, ER- $\beta 1$ is probably the only variant with sufficient abundance and affinity for estrogenic ligands to exert important neural effects, although alterations in splicing following neural damage cannot yet be ruled out.

ER- $\alpha$ and ER- $\beta$ share a structure that is similar to that of all members of the nuclear hormone receptor superfamily, and have highly homologous amino acid sequences in some domains, particularly the DNAbinding domain (Kuiper et al., 1996). Both have an activation function domain in the amino terminus (AF1), a central DNA binding domain and a carboxy terminus ligand binding domain, in which a second acti- vation function (AF-2) resides. In vivo, estrogen receptors exist in association as part of an oligomeric protein complex that includes heat shock proteins and immunophilins (Tsai and O'Malley, 1994). Upon binding to ligand, or following ligand-independent activation, estrogen receptors partially dissociate from this oligomer, and estrogen receptors form homo- and hetero-dimers (Cowley et al., 1997; Pettersson et al., 1997) that then bind to specific DNA sequences in target genes. The specific DNA sequences, termed estrogen response elements (EREs), are located in the promoter region of estrogen responsive genes, and influence the rate of gene transcription. Although characteristically formed by inverted repeat sequences, functional analyses of individual genes are necessary to identify EREs, because some estrogen response elements are formed by half-palindromic ERE-like motifs with a few mismatched base pairs (Donaghue et al., 1999; Aumais et al., 1996; Kato et al., 1992). For instance, promoter analyses have failed to identify perfect palindromic EREs in the promoter region of the mammalian ER- $\alpha$ gene (e.g. Donaghue et al., 1999; but see Le Drean et al., 1995 in trout and Lee et al., 1995 in frog), but half-ERE sites with one or a few mismatched base pairs are frequent, and may allow a functional estrogen response. Putative EREs have been identified in the promoter region of multiple genes that are both essential to normal brain function and implicated in brain disorders. Among these are the genes encoding choline acetyltransferase (Miller et al., 1999), the GABA transporter GAT-1 (Herbison et al., 1995), $\alpha 1$ a-adrenergic receptor (Lee et al., 1998), preproenkephalin (Zhu and Pfaff, 1995), oxytocin (Adan et al., 1993; Bale and Dorsa, 1997; Young et al., 1996), somatostatin (Xu et al., 1998a, Xu et al., 1998b), galanin (Kofler et al., 1995; Corness et al., 1997), glial fibrillary acidic protein (Stone et al., 1998b), brain-derived neurotrophic factor (Sohrabji, et al., 1995), transforming growth factor-alpha (El-Ashry et al., 1996), Fos (Weisz and Rosales, 1990), Myc (Dubik and Shiu, 1992), cyclin D1 (Sabbah et al., 1999) and Bcl-2 (Teixeira et al., 1995).

The finding of a new estrogen receptor subtype generated intense interest because of the underlying assumption that ER- $\alpha$ and ER- $\beta$ would regulate different target genes. Tissue specific expression and differences in the ratio and regulation of these two receptor subtypes may contribute to the wide diversity of tissue specific effects that occur in response to estrogen. The genes that are exclusively regulated by ER- $\alpha$ versus $-\beta$ are unknown, in part because attempts to identify unique ligands and antagonists have not yet led to huge success. However, in addition to differences in the distribution of the two receptor subtypes, differences in the impact on the nervous system of ER- $\alpha$ versus ER- $\beta$ knockouts have already been identified; 
for example, ER- $\alpha$ knockout mice are virtually incapable of masculine reproductive behaviors (Ogawa et al., 1997, 1998) and ER- $\alpha$ knockout females did not display sexual receptivity (Rissman et al., 1997), whereas reproductive behavior in ER- $\beta$ knockouts appears to be essentially normal (Ogawa et al., 1999). It is not yet known whether the neuroprotective effects are mediated through only one or both of these receptor subtypes or their splice variants.

During the last five years, a wealth of new information has accumulated on the mechanisms underlying estrogen receptor dependent gene activation. For example, it is now known that estrogen receptors interact with the basal transcriptional machinery through complex interactions with other transcription factors and with identified coactivators and adapter proteins (reviewed in Horwitz et al., 1996) which also remodel chromatin. These coactivators and adapter proteins may be present in limiting amounts and may impart transcriptional specificity. Sequences within coactivator proteins, such as the nuclear receptor interaction box, may also stabilize the binding of agonists to ER, effectively increasing the level of functional estrogen and modulating temporal aspects of estrogen action by profoundly slowing (over 50-fold in cell free dissociation assays) the dissociation rate of estrogen agonists (Gee et al., 1999). The effects of specific peptide sequences within these coactivators appear to interact with some ER subtype specificity. Another coactivator that may be important to estrogen action is the androgen receptor associated protein designated ARA-70 (Yeh et al., 1998). ARA-70 not only increases the efficacy of androgen induced AR transcriptional activity, but also allows estradiol to act as a ligand for androgen receptors, increasing $\mathrm{AR}$ transcriptional activity by up to 30-fold. Androgen receptors are expressed at moderate to high levels in many cells in regions that have been shown to benefit from estrogen's neuroprotective actions, including the hippocampal formation (Kerr et al., 1995), and the cerebral cortex (Simerly, 1990; Puy et al., 1995; Finley and Kritzer, 1999; McAbee and DonCarlos, 1998). Thus, some of the neuroprotective actions of estrogen may be mediated via estrogen's binding to androgen receptors, although whether ARA-70 is expressed in the nervous system has not been confirmed. In addition to interacting with estrogen response elements and possibly androgen response elements, estrogen receptors are able to affect transcriptional responses to other transcription factors, such as Jun and Fos at AP-1 sites (Paech et al., 1997), perhaps through protein-protein interactions that do not rely on binding to an estrogen response element (Webb et al., 1999). Results from molecular studies, largely carried out in cell culture, will need to be verified in vivo, and in specific tissues, to determine whether phenomena such as heterodimerization, cross- interference of steroid receptors, and ERE independent transactivation constitute important, physiologically relevant mechanisms for estrogen signal transduction. It will be of critical interest to determine which specific coactivators or adapter proteins are expressed in the nervous system and whether their expression and regulation can be manipulated to enhance the neuroprotective effects of estrogen.

In addition to estrogen receptors acting as transcription factors within nuclei, there is increasing and very exciting evidence that estrogen receptors may mediate the effects of estrogen via interaction with intracellular signaling cascades (e.g. Lagrange et al., 1996, 1997; Mermelstein, 1996; Singer et al., 1999; Singh et al., 1999; Toran-Allerand, 1996; Kelly et al., 1999; see also Section 3.2.3.3). Kelly, Ronnekliev and colleagues (Lagrange et al., 1996, 1997; Kelly et al., 1999) have established that estradiol can uncouple GABA-B and mu-opioid receptors from potassium channels via activation of protein kinase $\mathrm{A}$ and $\mathrm{C}$. Estrogen activates mitogen-activated protein kinase (MAPK) and B-ras (Singh et al., 1999), an effect that is involved in the ability of estrogen to protect against glutamate induced nerve cell death (Singer et al., 1999). G proteins are also activated by estrogen in the striatum, an area where membrane receptors have been hypothesized to exist (Mermelstein et al., 1996; Becker, 1999 and see discussion below). All of these effects are rapid and depend on the presence of estrogen receptor (or a putative membrane receptor, in the case of the striatum) but not on protein synthesis. These very exciting findings of convergent pathways for estrogen receptor

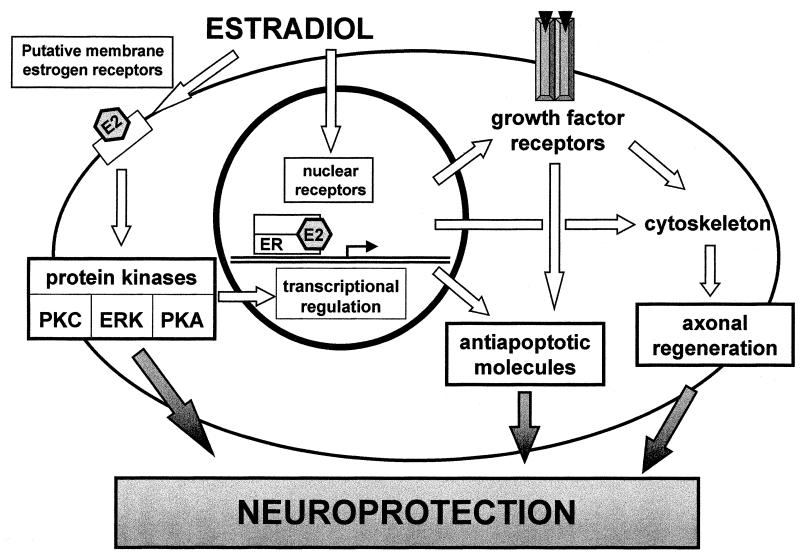

Fig. 4. Summary of mechanisms of neuroprotection dependent on the activation of estrogen receptors. Estradiol may bind to putative estrogen receptors in the plasma membrane and activate membrane associated signaling cascades. Alternatively, these signaling cascades may be activated by acting on other unidentified membrane binding sites (see Fig. 3). Estradiol may also act on conventional nuclear receptors and regulate transcription of growth factor receptors, cytoskeletal proteins and antiapoptotic molecules, all of them resulting in neuroprotection. 
modulation of cellular function have led to hypotheses that the trophic effects of estrogen and estrogen receptors involve complementary activation of transcription, via estrogen receptor binding to estrogen response elements, and estrogen receptor activation of signal transduction pathways, perhaps via ligand-induced release of constituents of the multimeric complex of the estrogen receptor complex (see Toran-Allerand et al., 1999 for a discussion), or via a membrane receptor (Fig. 4).

A putative membrane receptor for estrogen has been postulated for many years, (Ramirez and Zheng, 1996; Becker, 1999), supported primarily by electophysiological studies that demonstrated rapid effects of estrogen on the activity of neurons in a variety of brain regions (Foy et al., 1984; Smith et al., 1987, 1988; Kelly et al., 1999; and see reviews in Moss et al., 1997; Bicknell 1998; and Becker, 1999) and binding studies showing that estrogen binds to membrane fractions (Zheng and Ramirez, 1997). In addition, immunoreactivity for the classically defined nuclear estrogen receptors (discussed below) has been identified in axon terminals (Blaustein et al., 1992; Wagner et al., 1998). It is now thought that at least one class of these putative membrane estrogen receptors is synthesized from the same transcripts as the nuclear receptors and has a similar affinity for ligand (Razandi et al., 1999). These membrane estrogen receptors appear to function in estrogen signal transduction, in that estrogen rapidly activated G proteins, increased inositol phosphate synthesis and increased adenylate cyclase activity in either ER- $\alpha$ or ER- $\beta$ transfected Chinese hamster ovary cells (CHO cells). However, when either ER- $\alpha$ or ER- $\beta$ was overexpressed in CHO cells, over $95 \%$ of ER- $\alpha$ and $-\beta$ receptor protein was found in nuclear cell fractions, whereas less than 3\% was found in membrane fractions (Razandi et al., 1999). Whether the putative membrane estrogen receptors in the brain are derived from alternate post-translational processing of the classical nuclear estrogen receptor genes is not yet known. However, it is clear that rapid effects of estrogen, altering phosphorylation events or calcium release, could importantly modify the transcriptional regulatory effects of estrogen receptors, and may account for some of the "non-receptor" mediated effects described above (see Section 3.2.1).

\subsubsection{Estrogen receptor distribution in the central ner-} vous system. Steroid autoradiography, immunocytochemistry and in situ hybridization have been used to localize estrogen receptors in the nervous system. Each method provides a unique perspective on estrogen receptor biosynthesis and activity. Of primary importance is that the patterns of estrogen receptor expression found with each method match very closely, with some occasional exceptions (Toran-Allerand et al., 1992b). Extensive steroid autoradiographic studies have pointed to the remarkable evolutionary conservation of the regional distribution of estrogen receptor expression in the nervous system (Morrell and Pfaff, 1983).

The distributions of ER- $\alpha$ and ER- $\beta$ largely overlap (Li et al., 1997; Shughrue et al., 1997b, 1997d; the reader is referred to these articles for detailed descriptions of the precise distribution of ER- $\alpha$ and $-\beta$ expressing cells in the brain), and the two receptor subtypes are expressed in the same cells in some regions (Shughrue et al., 1998). The regions with the highest densities of cells expressing estrogen receptors are found in the forebrain, in the preoptic area, hypothalamus and amygdala, particularly in subdivisions of these regions that are vital to reproductive function (Pfaff and Keiner, 1973; Warembourg et al., 1989; DonCarlos et al., 1991), and in the peripheral nervous system, in the dorsal root ganglion (Sohrabji et al., 1994a; Taleghany et al., 1999). Estrogen receptor beta mRNA expression is higher than ER- $\alpha$ expression in the paraventricular nucleus and much higher in the medial tuberal nucleus, whereas ER- $\alpha$ mRNA expression is much greater than ER- $\beta$ expression in the ventromedial and arcuate nuclei of the hypothalamus.

The proportion of total cells that are estrogen targets in a brain region, and the amount of binding per cell, as determined using steroid autoradiography, is highest in the medial amygdala, followed by the ventromedial nucleus, preoptic area and arcuate nucleus (Morrell et al., 1986). Immunocytochemical studies of estrogen receptor alpha protein have found a roughly similar pattern (e.g., Wood and Newman, 1995). The development of antibodies and mRNA detection methods for localization of estrogen receptors has provided enhanced sensitivity for identification of cells with lower levels of estrogen receptor expression per cell, as is characteristic for estrogen target areas that are not classically identified with reproduction. Although the amount of estrogen receptor per cell and the total proportion of cells that are estrogen targets in areas such as the cerebral cortex, hippocampal formation, and midbrain raphe may be lower than found in the hypothalamus and amygdala, nevertheless the total number of such cells may in fact be much greater overall than found in the hypothalamus-preoptic continuum and amygdala. Therefore, the potential impact of estrogen, via estrogen receptor activation, in extra-hypothalamic, extra-amygdaloid regions should not be underestimated.

There is little doubt that the preponderance of highlevel estrogen receptor expression, that is amount of protein per cell, occurs in neurons under normal conditions. A steroid autoradiographic study, using a highly sensitive iodinated synthetic estrogen, showed that estrogen concentrating cells are immunopositive 
for neurofilament protein, but not glial fibrillary acidic protein (Brown et al., 1993). However, as discussed below, low levels of estrogen receptor immunoreactivity have been identified in oligodendrocytes and astrocytes of the hypothalamus, using ultrastructural techniques (Langub and Watson, 1992). Moreover, using confocal microscopy to detect cells double labeled for estrogen receptor and glial markers, estrogen receptors have been identified in astrocytes (Azcoitia et al., 1999c), microglia (Mor et al., 1999) and a variety of other glial cell types (Gudino-Cabrera and Nieto-Sampedro, 1999). Given that glial cells outnumber neurons, it is possible that more glial cells express estrogen receptor than do neurons, albeit at much reduced levels. Quantitative studies to determine the proportion of specific glial cell types that express estrogen receptor alpha and beta, and the frequency of these cells in different brain regions, remain to be performed.

In many regions of the adult rat nervous system, levels of ER- $\alpha$ mRNA expression are higher in females than in males. Generally, estrogen down-regulates ER$\alpha$ mRNA, but even when estrogen levels are at their highest and ER levels at their lowest, adult females exhibit higher levels of ER- $\alpha$ mRNA (Simerly and Young, 1991; Shughrue et al., 1992) and ER protein (Zhou et al., 1995) than do males; males apparently have a lower capacity to synthesize ER. It is not known whether this sex difference in synthetic capacity is limited to specific brain regions and normal versus injured brains. To date, there is little information about hormonal regulation and sexual differentiation of ER- $\beta$ expression.

With regard to neuroprotection and estrogen receptor regulation, aromatase levels (Garcia-Segura et al., 1999a) and estrogen receptor levels (Dubal et al., 1999) are upregulated following injury to the central nervous system. We would have predicted that increases in local estrogen synthesis would be accompanied by decreased ER synthesis, the opposite of what actually occurs. The increase in ER- $\alpha$ expression is restricted to those areas that express high levels of ER during development. Together, these data support the argument that injury initiates a survival response that requires enhanced levels of both ligand and receptor. What neurotransmitters or other factors are released upon injury and participate in the upregulation or disinhibition of estrogen receptor synthesis is an open question. Noradrenaline is one neurotransmitter implicated in modulation of estrogen receptor levels and responses to estrogen under normal conditions (Clark et al., 1985; Tetel and Blaustein, 1991).

The localization of estrogen receptors is not the only factor determining the role of estrogen within a given area. Estrogen receptor activation has regionally specific consequences. A key example of this is found in the anteroventral preoptic area $(\mathrm{AvPv})$ and sexually dimorphic nucleus of the preoptic area (SDN-POA). Both areas express estrogen receptors during development (Kuhnemann et al., 1994; DonCarlos and Handa, 1994; DonCarlos et al., 1995), and are functionally related, yet estrogen promotes survival of SDN-POA neurons (Dohler et al., 1984) and death of AvPv neurons (Arai et al., 1996; Davis et al., 1996). In addition to demonstrating that estrogen can exert opposite effects in related estrogen receptor expressing regions, these findings also serve to underscore the fact that estrogen may not be universally neuroprotective.

\subsubsection{Estrogen receptor mediated neuroprotection.} Several lines of evidences suggest that neuroprotective effects of estradiol may be at least in part mediated by the activation of estrogen receptors. The neurotrophic action of estradiol in primary hippocampal cultures is reduced by substances, such as geldanamycin, that disrupt mature steroid receptor complexes (Gold et al., 1999). Molybdate (20 mM), which prevents the disruption of mature steroid receptor complexes, also decreases the neurotrophic activity of estradiol (Gold et al., 1999). This finding indicates that components of steroid receptor complexes may be involved in the neuroprotective effect of the hormone. A direct proof of the involvement of estrogen receptor on cell survival has been obtained in PC12 cells. Estrogen enhances the survival of PC12 cells transfected with the fulllength rat estrogen receptor alpha, but does not affect the survival of control cells transfected with vector DNA alone (Lustig, 1996; Gollapudi and Oblinger, 1999a; 1999b). There is also evidence that estrogen receptor is involved in the regulation of neuronal survival in primary cultures. Estrogen enhancement of neuronal survival in primary hypothalamic cultures in the serum-free medium and in cortical cultures exposed to glutamate is blocked by the estrogen receptor antagonists tamoxifen (Chowen et al., 1992; Singer et al., 1996b) and ICI 182, 780 (Dueñas et al., 1996; Singer et al., 1999). In addition, antiestrogens abolish the neuroprotective action of $17 \beta$-estradiol in cultures of dorsal root ganglion neurons deprived of nerve growth factor (Patrone et al., 1999). All of these findings provide evidence that estrogen may promote neuronal survival in vitro by an effect mediated via estrogen receptors. The dependence of neuroprotective effects of estradiol on estrogen receptors has been demonstrated in vivo as well. The intracerebroventricular administration of the estrogen receptor antagonist ICI 182, 780 inhibits the neuroprotective effect of estradiol in hippocampal hilar neurons of ovariectomized rats exposed to systemic kainic acid (Azcoitia et al., 1999b). Furthermore, the selective estrogen receptor modulator raloxifene prevents MPTP-induced dopaminergic depletion in mice (Grandbois et al., 2000). 


\subsubsection{Potential molecular targets of estrogen receptor- mediated neuroprotection}

\subsubsection{Regulators of synaptic sprouting and axonal re-} generation. It is well established that estradiol regulates synapse formation during development and induces synaptic plasticity in the adult brain (Matsumoto, 1991; Garcia-Segura et al., 1994; McEwen, 1996; Woolley, 1998). These hormonal effects are involved in the sexual differentiation of synaptic connectivity and in the physiological regulation of adult brain function. In addition, since the pioneering work of Matsumoto and Arai (1979), it has been known that estrogen may promote synaptic sprouting in response to injury. These authors tested the effect of estrogen in the arcuate nucleus after deafferentation, a treatment that results in a loss of axo-dendritic synapses. Treatment with estradiol benzoate for three weeks, beginning on the day of surgery, effectively restored the axodendritic synaptic population of the deafferented arcuate nucleus in adult ovariectomized rats (Matsumoto and Arai, 1979, 1981). Further studies have shown that the arcuate nucleus of aged female rats still retains plasticity to react to deafferentation under the influence of estrogen (Matsumoto et al., 1985). Other studies have shown that estrogen enhances synaptic sprouting in the hippocampus of ovariectomized female rats after entorhinal cortex lesions (Morse et al., 1986, 1992) and that estrogen accelerates regeneration rates of injured facial motoneurons (Tanzer and Jones, 1997).

Many different molecules, including cytoskeletal components, adhesion molecules and soluble factors, participate in the process of axonal growth and axonal target recognition. These molecules include growth factors and neurotrophins (Fig. 4). The possible role of growth factors and neurotrophins in the neuroprotective effects of estradiol is discussed in Section 3.2.3.3. Little is known about the role of adhesion and guidance molecules, such as semaphorins, on the neuroprotective effects of estradiol. In contrast, it is known that estradiol induces the expression of tau in axons and this may result in the stabilization of microtubules and the promotion of axonal growth (Ferreira and Caceres, 1991; Lorenzo et al., 1992; Diaz et al., 1992). Another protein that may be involved in estrogeninduced axonal regeneration is GAP-43. GAP-43, also known as B-50, is a presynaptic protein implicated in the growth and regeneration of axons (Oestreicher et al., 1997). The expression of GAP-43 is modulated by estrogen in the preoptic area of developing and adult rats (Shughrue and Dorsa, 1993) and in the mediobasal hypothalamus of adult rats (Lustig et al., 1991). Levels of GAP-43 decline in aged rats. Interestingly, estrogen restores GAP-43 mRNA in 24 month old rats to levels comparable to that seen in young animals (Singer et al., 1996a).
The effect of estrogen on synaptic sprouting may be mediated by the up-regulation of ApoE expression (Stone et al., 1998a; Teter et al., 1999). ApoE is involved in lipid and cholesterol metabolism and it may be involved in the mobilization and reutilization of lipid in the repair, growth, and maintenance of myelin and axonal membranes, both during development and after injury. Furthermore, the epsilon 4 allele of ApoE has a direct impact on cholinergic function in Alzheimer's disease (Poirier, 1994; see also Section 2.1.2). The synthesis of ApoE is dramatically increased after injury of peripheral nerves (Ignatius et al., 1986; LeBlanc and Poduslo, 1990) and in the central nervous system (Poirier, 1994). Although nerve regeneration may occur in ApoE deficient mice (Popko et al., 1993; de Chaves et al., 1997), these animals show an increased central neuronal damage after cerebral ischemia and other forms of cerebral injury (Chen et al., 1997a, 1997b; Sheng et al., 1999; Horsburgh et al., 1999), suggesting that ApoE may be a factor involved in brain repair. Stone et al. (1998a) have shown that estrogen enhances synaptic sprouting in response to an entorhinal cortex lesion in wild-type and not in ApoEknock-out mice. Furthermore, synaptic sprouting is increased by estrogen in the same regions where sprouting is dependent on ApoE (Teter et al., 1999).

3.2.3.2. Regulators of cell death. Estrogen's neuroprotective effects may involve, at least in part, a modulation of the expression of molecules involved in the control of cell death (Figs. 4 and 5). The family of Bcl-2-related proteins is involved in the regulation of cell death of many cell types, including neurons. Some members of this family are negative regulators of cell death, such as Bcl-2 and Bcl-XL. Other members, such as Bax and Bad, are positive regulators of cell death. Estradiol has been shown to promote the expression of Bcl-2 in NT2 neurons (Singer et al., 1998) and in adult neurons in vivo (Garcia-Segura et al., 1998) and the expression of Bcl-XL in PC12 cells (Gollapudi and Oblinger, 1999a; Gollapudi and Oblinger, 1999b) and

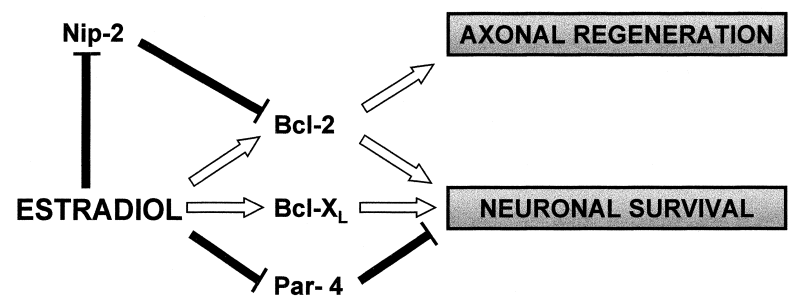

Fig. 5. Described effects of estradiol on molecules that regulate programmed cell death. Estradiol downregulates the proapoptotic molecules Nip-2 and Par-4 and upregulates the antiapoptotic molecules $\mathrm{Bcl}-2$ and $\mathrm{Bcl}-\mathrm{XL}$ in neurons and neuronal cell lines. Acting on Bcl2 , estradiol may directly affect neuronal survival by blocking caspase activation and indirectly by the promotion of axonal regeneration. 
in cultured hippocampal neurons (Pike, 1999). Identification of estrogen receptor target genes by mRNA differential display PCR in human neuroblastoma SKER3 cells has revealed that the mRNA for the Bcl-2 interacting protein Nip2 is decreased by estrogen treatment (Garnier et al., 1997). Nip-2 expression is also down-regulated by estradiol in monoblastoid cells (Vegeto et al., 1999). Since Nip2 is a negative regulator of $\mathrm{Bcl}-2$, estrogen may promote $\mathrm{Bcl}-2$ expression by this mechanism (Fig. 5). In addition, estradiol may directly affect transcription of bcl-2 gene, since several putative estrogen-responsive sites are present in the bcl-2 promoter (Teixeira et al., 1995).

The hormonal regulation of the expression of the members of the Bcl-2 family is associated with the neuroprotective effects of estradiol. For instance, estradiol enhances the survival of $\mathrm{PC} 12$ cells transfected with the full-length rat estrogen receptor alpha and this effect is associated with an increased expression of Bcl$\mathrm{XL}$ and a reduced expression of Bad (Gollapudi and Oblinger, 1999b). An increased expression of Bcl-2 is associated with the hormonal protection of NT2 neurons from $\mathrm{H}_{2} \mathrm{O}_{2}$ or glutamate induced cell death (Singer et al., 1998). Estrogen significantly increases the expression of the antiapoptotic protein Bcl-XL in cultured hippocampal neurons and this induction is associated with a reduction in apoptosis induced by beta-amyloid (Pike, 1999). Furthermore, 17ß-estradiol increases survival of cultured dorsal root ganglion neurons deprived of nerve growth factor and this effect is associated with an increased expression of $\mathrm{Bcl}-\mathrm{X}$ without affecting the expression of Bax (Patrone et al., 1999). Dubal et al. (1999) have found that estradiol prevents the down regulation of bcl-2 expression in the rat cerebral cortex induced by ischemia. Since this effect is accompanied by an increased ratio of estrogen receptor beta/estrogen receptor alpha expression, Dubal et al. (1999) propose that estradiol decreases the extent of cell death after ischemia by an estrogen receptor-beta mediated effect on Bcl-2. In addition to preventing neuronal death, Bcl-2 may also promote axonal growth and axonal regeneration (Chen et al., 1997a, 1997b; Holm and Isacson, 1999). Therefore, by the induction of Bcl-2, estradiol may promote neuronal survival after injury both by Bcl-2-induced inhibition of cell death and by Bcl-2-induced facilitation of regeneration of neuronal connectivity (Fig. 5). Furthermore, Bcl-2 attenuates the generation of reactive oxygen species (Bogdanov et al., 1999) and estradiol may therefore reduce oxidative stress in neural tissue by the induction of Bcl-2 expression.

Another protein that regulates cell death and is a target of estradiol is the prostate apoptosis response- 4 (Par-4), the product of a gene up-regulated in prostate cancer cells undergoing apoptosis. Par-4 expression is induced in neurons after exposure to trophic factor deprivation and apoptotic insults (Guo et al., 1998; Chan et al., 1999; Duan et al., 1999a, 1999b) and is up-regulated in vulnerable neurons in Alzheimer's disease brains (Guo et al., 1998). Par-4 antisense treatment suppresses mitochondrial dysfunction and caspase activation in synaptosomes and prevents cell death of cultured hippocampal neurons following exposure to excitotoxic and apoptotic insults (Duan et al., 1999a). Interestingly, both Par-4 induction and cell death induced by trophic factor deprivation in cultured hippocampal neurons are largely prevented by pretreatment of the cultures with 17 $\beta$-estradiol (Chan et al., 1999). Since increases in Par-4 expression follow an increase of reactive oxygen species, and precede mitochondrial membrane depolarization, caspase activation, and nuclear chromatin condensation/ fragmentation, the down-regulation of Par-4 expression by estrogen may be one of the mechanisms involved in the antioxidant and neuroprotective effects of the hormone (Fig. 5).

\subsubsection{Growth factors}

Neurotrophins. Since the pioneering work of ToranAllerand et al. (1992a, 1992b), it has been well established that estrogen and neurotrophins interact in many areas of the nervous system. Estrogen regulates the expression of neurotrophins and their receptors and neurotrophins regulate the expression of estrogen receptors in different neuronal populations. For instance, nerve growth factor significantly increases nuclear estrogen binding in cortical explants (Miranda et al., 1996). In turn, estrogen regulates the expression of p75 and of trkA in dorsal root ganglion neurons from adult rats (Sohrabji et al., 1994a) and in PC12 cells (Sohrabji et al., 1994b). The hormone regulates the expression of mRNA for brain-derived neurotrophic factor and nerve growth factor in the hippocampus and frontal cortex (Simpkins et al., 1997a), decreases the expression of NGF in the hippocampus and of trkA in the medial septum and nucleus basalis magnocellularis (Gibbs et al., 1994) and increases the expression of trkA in the basal forebrain of adult female rats (McMillan et al., 1996). By decreasing the expression of brain-derived neurotrophic factor, estrogen induces dendritic spine growth in hippocampal neurons (Murphy et al., 1998). This co-regulation of neurotrophins and estrogen receptors may be regulated by cell to cell interactions or may occur in the same neuron, since estrogen receptors and neurotrophin receptors are coexpressed in some cells.

In 1992, Toran-Allerand et al. reported that estrogen receptors colocalize with $\mathrm{p} 75$, the low-affinity nerve growth factor receptors, in cholinergic neurons of the basal forebrain (Toran-Allerand et al., 1992b). Further studies have shown a widespread colocalization of estrogen and neurotrophin receptors within estrogen and 
neurotrophin targets, including neurons of the cerebral cortex, sensory ganglia and PC12 cells (Sohrabji et al., 1994a, 1994b; Miranda et al., 1994; Toran-Allerand, 1996; Toran-Allerand et al., 1999). These findings indicate that estrogen and growth factors may act in concert on the same neuron to regulate the expression of specific genes that may influence neuronal survival (Toran-Allerand et al., 1992b; Toran-Allerand, 1996). Furthermore, the colocalization of estrogen receptors and neurotrophin receptors in the same neurons leads to convergence or cross-coupling of their signaling pathways. In addition, estradiol may directly activate the signaling pathways of growth factors without the involvement of intracellular estrogen receptors. For instance, estradiol has been shown to elicit rapid and sustained tyrosine phosphorylation and activation of the mitogen-activated protein kinases ERK1 and ERK2 in cerebral cortical explants and neuroblastoma cells. ERK activation is not inhibited by the estrogen receptor antagonist ICI 182,780 and may depend on an increase in B-Raf kinase activity (Watters et al., 1997; Singh et al., 1999; Toran-Allerand et al., 1999). In addition, estrogen induced neuroprotection in primary cortical cultures exposed to glutamate is associated with a rapid activation of tyrosine kinase and MAPK activity (Singer et al., 1999).

It is still unknown whether estrogen and neurotrophins act in concert to promote neuronal survival after neural injury in vivo. However, an interaction of estrogen and NGF has been documented in terminally differentiated PC12 cells transfected with the estrogen receptor alpha. Estrogen and NGF act synergistically to protect these cells from apoptosis induced by serum deprivation (Gollapudi and Oblinger, 1999b). This synergistic effect was not observed in control PC12 cells transfected with vector DNA (Gollapudi and Oblinger, 1999b), suggesting that the synergistic action of estrogen and NGF on neuroprotection is dependent on estrogen receptor. Further studies are still needed to determine the extent of the interaction of estrogen and neurotrophins in different models of brain injury.

Insulin-like growth factor I. Insulin-like growth factor I (IGF-I) has prominent neurotrophic effects, stimulating differentiation and survival of specific neuronal populations (Torres-Aleman et al., 1990, 1994; Beck et al., 1995; De Pablo and De la Rosa, 1995). Trophic effects of IGF-I are mediated by IGF-I receptor, a member of the growth factor tyrosine kinase receptor family that signals through the phosphoinositol-3 kinase pathway and the mitogen-activated protein kinase (MAPK) cascade. IGF-I and estrogen have interactive effects on neurons. The first evidence for this was provided by Toran-Allerand et al. (1988), showing that in explant cultures of fetal rodent hypothalamus, estrogen and insulin have a synergistic action on neuritic growth, an effect probably mediated by IGF-I receptors. Subsequent studies showed that estrogen modulates IGF-I receptors and binding proteins in monolayer hypothalamic cultures (Pons and Torres-Aleman, 1993). Both IGF-I and estrogen promote survival and differentiation in primary hypothalamic cultures. Interestingly, in this system the effect of estrogen is dependent on IGF-I and the effect of IGF-I is blocked by the estrogen receptor antagonist ICI 182, 780 (Dueñas et al., 1996). Furthermore, IGF-I receptor activation is necessary for estrogen induction of glial and synaptic plasticity in the hypothalamus in vivo (Fernandez-Galaz et al., 1997, 1999).

The possible interaction of the neuroprotective effects of estradiol and IGF-I after injury have also been tested in vivo, by assessing neuronal survival in the hilus of the dentate gyrus after systemic administration of kainic acid to ovariectomized rats. Either IGF-I or estradiol is able to protect hippocampal neurons from kainic acid-induced degeneration (Azcoitia et al., 1998, 1999b). The administration in the lateral cerebral ventricle of a specific IGF-I receptor antagonist, the peptide $\mathrm{JB} 1$, resulted in the prevention of the neuroprotective effects of estrogen in this model, indicating that the hormonal effect is dependent on IGF-I receptors. Furthermore, the neuroprotective effect of IGF-I was blocked by ICI 182,780, indicating that activation of estrogen receptors is necessary for the effect of IGF-I on hippocampal neurons. These findings suggest that the neuroprotective effect occurs only when both IGF-I receptor and estrogen receptor signaling pathways are activated. Since the production of estrogen and its precursor androgens, as well as the production of IGF-I, decline with aging in humans (Lamberts et al., 1997), the interaction of estrogen and IGF-I signaling in neuroprotection may be relevant to the increased vulnerability to neurodegeneration in old age.

Several points of convergence of IGF-I and estradiol signaling may be involved in neuroprotection. For instance, both estradiol and IGF-I activate MAPK. MAPK interferes with c-Jun $\mathrm{N}$-terminal protein kinase activation, protecting cells from apoptosis (Cheng and Feldman, 1998). On the other hand, it has been shown that IGF-I and other growth factors may activate estrogen receptors in different cell types, including SKER3 neuroblastoma cells transfected with the estrogen receptor. This activation may occur even in the absence of estradiol and it is exerted via the ras-pathway in SK-ER3 neuroblastoma cells (Agrati et al., 1997). Therefore IGF-I may in part regulate neuroprotection by direct activation of estrogen receptors. Other possible molecules that may be involved in the convergence of estrogen and IGF-I actions are those of the Bcl-2 family, since both estradiol and IGF-I induce the expression of the antiapoptotic regulator Bcl-2 in adult rat brain (Garcia-Segura et al., 1998; 
Fernandez et al., 1999). Another possible common target for estrogen and IGF-I is NF- $\kappa$ B. This transcription factor may be involved in the protection of neurons from excitotoxic injury, oxidative stress and amyloid-beta induced neuronal death (Heck et al., 1999; Kaltschmidt et al., 1999; Yu et al., 1999). NF-кB mediates IGF-I induced neuroprotection (Heck et al., 1999), the p65 subunit of $\mathrm{NF}-\kappa \mathrm{B}$ heterodimer represses estrogen receptors via a physical interaction (McKay and Cidlowski, 1998), estrogen activates $\kappa$ B-specific proteins in the uterus (Shyamala and Guiot, 1992) and estrogen receptor alpha may regulate the expression of genes under the control of $\mathrm{NF}-\kappa \mathrm{B}$ response elements (Cerillo et al., 1998).

\subsection{Glia versus neurons}

Estrogen may directly or indirectly target cellular components of the nervous system other than neurons. Indeed, the protective effect of estradiol in transient forebrain ischemia may be related in part to an improvement of the vasodilating capacity (Hurn et al., 1995; Pelligrino et al., 1998) and to prevention of brain capillary endothelial cell loss which may in turn reduce focal ischemic brain damage (Shi et al., 1997). In addition, chronic estrogen depletion by ovariectomy enhances leukocyte adhesion in the rat cerebral circulation while estrogen repletion is accompanied by a significant reduction in leukocyte adhesion (Santizo and Pelligrino, 1999).

Glial cells are an essential component of normal neural function as well as of the response of neural tissue to injury. There is now substantial evidence that glial cells are targets for steroid hormones (GarciaSegura et al., 1996; Jordan, 1999; Langub and Watson, 1992; Nichols, 1999; Vardimon et al., 1999; Finley and Kritzer, 1999) and participate in steroid synthesis (Koenig et al., 1995; Zwain and Yen, 1999) and metabolism (Melcangi et al., 1999). Glial cells mediate different actions of gonadal steroids in the regulation of the development and plasticity of specific neuronal populations and in the control of neuroendocrine events (Garcia-Segura et al., 1996, 1999b; Jordan, 1999; Melcangi et al., 1999; Mong and McCarthy, 1999; Ojeda and Ma, 1999). Furthermore, glial cells may be involved in the regenerative and neuroprotective effects of gonadal hormones (Garcia-Segura et al., 1999b; Jones et al., 1999; Melcangi et al., 1999; Nichols, 1999).

Estrogen receptors have been detected in different populations of glial cells (Azcoitia et al., 1999c; Gudino-Cabrera and Nieto-Sampedro, 1999; Mor et al., 1999) and estrogen regulates the morphology and gene expression of glia (Garcia-Segura et al., 1996, 1999b; Stone et al., 1998b). Furthermore, estrogen may regulate the proliferation of glia and the for- mation of reactive gliosis: the hormone inhibits microglia proliferation in vitro (Ganter et al., 1992) and down-regulates the proliferation of astrocytes after injury and the accumulation of reactive astrocytes in the lesioned brain area in both male and female rats (Garcia-Estrada et al., 1993, 1999). These effects of estrogen on gliosis may be a contributing factor for neural regeneration. Estrogen may regulate the production of cytokines by the gliotic tissue that may be deleterious for neurons. For instance, estradiol decreases the activation of $\mathrm{NF}-\kappa \mathrm{B}$ in cultured rat astroglial cultures following exposure to amyloid beta(1-40) and lipopolysaccharides (Dodel et al., 1999). Although NF-кB expression in neurons may promote neuroprotection (see "Neurotrophins", p. 45), this transcription factor is also a potent immediateearly transcriptional regulator of numerous proinflammatory genes. Estrogen may therefore decrease the inflamatory response after brain injury by decreasing the activation of $N F-\kappa B$ in astrocytes. In addition, by acting on glial cells, estrogen may regulate the release of factors, such as growth factors and neurotrophins, that promote neuronal survival and axonal regeneration. One of these factors is ApoE (see Sections 2.1.3 and 3.2.3.1). As mentioned before (Section 3.2.3.1), ApoE is involved in the effects of estrogen on axonal sprouting. Interestingly, estrogen increases the expression of ApoE in astrocytes and microglia in vitro and in vivo (Stone et al., 1997), suggesting that these two glial cell types may be involved in the reparative effects of estrogen in the central nervous system. Since immunoreactivity for estrogen receptor beta has been detected in both microglia and astroglia (Azcoitia et al., 1999c; Mor et al., 1999), it is possible that estrogen may directly act on these cells to regulate the production of ApoE.

Glial cells, in addition to mediating hormonal effects, may also produce neuroprotective steroids, including estradiol. Aromatase, the enzyme that produces estrogen from androgen precursors, is induced de novo in astrocytes by the systemic administration of kainic acid or by introducing a cannula in the brain parenchyma of rats and mice (Garcia-Segura et al., 1999a). This finding suggests that local production of estrogen is one of the mechanisms used by the central nervous system to cope with neurodegeneration and emphasizes the significance of estradiol as a neuroprotectant (Fig. 6).

\section{Prospectives for future studies}

\subsection{Estrogen and adult neurogenesis}

The ability to induce proliferation and functional incorporation of new neurons in the adult brain would 
represent the ultimate form of neuroprotection. It has been understood for some time that new neurons are in fact born and functionally incorporated into the olfactory neuroepithelium. More recently, adult neurogenesis has been recognized in many species and more than one brain region (Alvarez-Buylla and Lois, 1995), including the higher vocal center of song birds where neurons are replaced seasonally (Barnea and Nottebohm, 1994; Alvarez-Buylla and Kirn, 1997), and the dentate gyrus of the hippocampal formation of mammals, where it was first observed by Altman and Das (1965).

A potential role for estradiol in production of hippocampal granule cells has been investigated by Gould et al. (1999). These investigators found that, following injection with bromodeoxyuridine (BrdU), a thymidine analog that labels dividing cells, females had significantly more newly generated cells in the dentate gyrus than did males. The delay between final division and incorporation into the granule cell layer was approximately 3 weeks. By 3 weeks (and even earlier), there was no overall sex difference in the total number of granule neurons, perhaps because more of the newly generated cells die in females. Neurogenesis is not only different in males and females, it also fluctuates with the estrous cycle. The number of newly generated cells in the dentate gyrus was $50 \%$ higher in females injected with BrdU on proestrus (estradiol levels high) versus females injected on estrus or diestrus (estradiol levels low). Estrogen treatment reversed ovariectomy induced decreases in the rate of neurogenesis. Moreover, the number of dying cells is altered by circulating hormones, since $40 \%$ fewer pyknotic cells were observed in proestrus females vs those sacrificed at other stages of the cycle. Similarly, some investigators

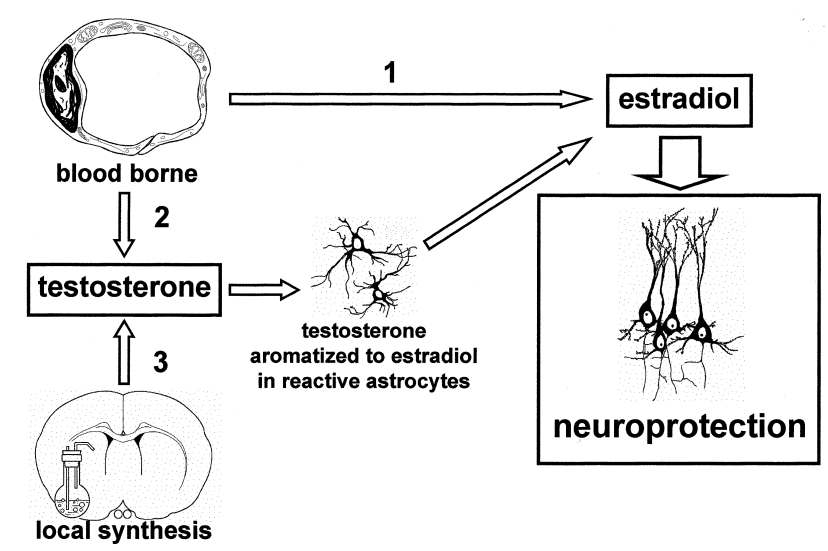

Fig. 6. Possible sources of estradiol for injured neurons in the central nervous system. Estradiol may reach neurons directly from the circulation (1), after local conversion of peripheral testosterone by reactive astroglia (2), and after local conversion of locally-formed testosterone by reactive astroglia (3). Route 1 is of particular significance in females while route 2 will be of particular significance in males. Route 3 may operate in both sexes. have found that estrogen promotes survival of newly generated neurons in the bird song control regions (Hidalgo et al., 1995; Burek et al., 1995). Estrogeninduced alterations in neurogenesis may be direct or may involve estrogen-dependent modifications of the hypothlamo-pituitary-adrenal axis, since adrenal steroids inhibit proliferation of cells destined for the granule cell layer (Gould et al., 1992), but this remains to be established. Brief mention should be made respecting one potential technical caveat in evaluating those studies that use BrdU as a marker for newly generated cells, particularly with respect to effects of estrogen on the genesis and survival of neurons. Kolb et al. (1999) recently reported that $\mathrm{BrdU}$ is toxic to the embryonic brain. Also, earlier reports had shown that BrdU interferes with estrogen signaling (Kallos et al., 1978; Garcia et al., 1981). Confirmation of BrdU results with results based on other techniques to identify proliferative populations is therefore warranted.

The functional significance of continual replenishment of dentate granule cell neurons, and why estrogen modifies replacement of neurons in the dentate gyrus is unknown. One proposal is that the continuous replacement of neurons in the dentate gyrus provides a refreshable repository for temporary processing of new information that is later moved elsewhere for long term storage (Tanapat et al., 1999). Neuron addition in the hippocampal formation does appear to be accelerated under conditions that require or enhance learning (Gould et al., 1999; Huang et al., 1998; Kempermann et al., 1997), as observed in the avian vocal control pathways (Nordeen, 1990; AlvarezBuylla and Kirn, 1997). Higher estradiol levels may signal a physical (e.g. pregnancy) or environmental (e.g. change of season) challenge that requires augmented memory acquisition. Since neurogenesis in the hippocampus declines with age (Cameron and McKay, 1999), as do estrogen levels at menopause, these concurrent events may precipitate decreased cognitive functioning with age in some individuals.

Potential estrogen-dependent alterations of neurogenesis may also be of considerable clinical interest with the development of neural stem cell technology for replacing lost neurons. In hamsters, androgens enhance the functional incorporation into the olfactory bulb of progeny derived from the subventricular zone (Huang et al., 1999), and in mice, the hormones of pregnancy enhance neurogenesis (Kaba et al., 1988). Estrogen may help to coax the differentiation of endogenous or exogenously applied neural stem cells into regionally appropriate and transmitter specific phenotypes. One potential mechanism through which estrogen may modulate neuropoiesis could involve interactions with growth factors, as discussed in Section 3.2.3.3. For example, estrogen upregulates expression of brain derived neurotrophic factor (BDNF) 
mRNA and protein in numerous brain regions (Gibbs, 1999), including the cortex and hippocampal formation (Singh et al., 1995). BDNF, in turn, promotes generation and survival of neurons derived from subventricular zone precursors (Goldman, 1998; Zigova et al., 1998). Exogenous epidermal growth factor (EGF) promotes differentiation of subventricular zone progeny into astrocytes rather than neurons, whereas basic fibroblast growth factor-2 (FGF-2) promotes an increase in the total number of newborn cells and development of a neuronal phenotype in progeny (Kuhn et al., 1997; Palmer et al., 1999) in the rat, and like other neurotrophic factors (Toran-Allerand, 1996), may be regulated by estrogen in the brain. Therefore, it is conceivable that estrogen will modulate neuropoiesis and the fate of progeny via interaction with growth factors. It is clearly of vital clinical importance to evaluate the potential therapeutic role of estrogen in stimulation of proliferation and survival of endogenous neural stem cells, on the one hand, and on the other hand, in orchestration of topographically accurate migration and targeted differentiation of transplanted neural stem cells.

\subsection{Estrogen receptor regulation following injury}

In development, estrogen receptors are transiently expressed at high levels in some areas where they are not expressed in adulthood, such as the facial motor nucleus (Hayashi, 1994) or are expressed at much lower levels in the adult than the neonate, as in the hippocampal formation (O'Keefe and Handa, 1990; O'Keefe et al., 1995). Neural repair has been proposed to involve, in part, reinitiation of developmental programs by injured neurons. Estrogen receptors may therefore play a role in survival or differentiation of neurons in these regions. Estrogen receptor expression is induced following injury (Dubal et al., 1999) in regions of the cerebral cortex that produce higher levels of receptor developmentally (Shughrue et al., 1990; Yokosuka et al., 1995), and may play a protective role in both instances. Estrogen accelerates recovery of function of facial motor neurons following axotomy (Tanzer and Jones, 1997), although recapitulation of developmental estrogen receptor expression does not appear to be involved (Tanzer et al., 1999). Whether estrogen receptor induction following neurologic impairment occurs only in those areas that express the receptors during development or adulthood or is a more global injury response is unknown. If estrogen receptors are proven to be uniformly beneficial to the injury response, then, as discussed above for the induction of neurogenesis, means by which estrogen receptor expression can be selectively augmented in targeted regions should be sought.
4.3. Estrogenic ligands, receptors, and other mechanisms of action

A major area of current effort in endocrinology is the search for ligands that selectively target estrogen receptors in specific tissues and provide benefits, such as prevention of osteoporosis or heart disease, without promoting the development of hormone dependent cancers. Similarly, estrogenic ligands that act in specific regions on specific subsets of neurons or glia would be ideal, not only to prevent the potentially harmful peripheral effects of estrogen, but also because the positive versus negative effects of estrogen within the nervous system are likely to be brain region dependent. For example, estrogen is toxic to neurons in the arcuate nucleus of the hypothalamus, specifically those that produce $\beta$-endorphin (Desjardins et al., 1995), where it is thought to accelerate the onset of reproductive senescence. Additionally, in the sexually dimorphic nucleus of the preoptic area of aging male rats, the loss of neurons is more severe following estrogen treatment (Hsieh et al., 1996). Developmentally, estrogen has opposite effects on survival even in neighboring and functionally related neuronal populations, where it spares some neurons (for example, in the sexually dimorphic nucleus of the preoptic area) while killing others (anteroventral periventricular nucleus of the preoptic area) (Arai et al., 1996).

The above discussion highlights the need to learn more about the various mechanisms of action of estrogen in normal function as well as neuroprotection. If the mechanism of action of estrogen is due to a nonspecific enhancement of neural activity, then the effects of estrogen in neuroprotection should be similar to those of other general stimulants. More needs to be known about the anti-oxidant effects of estrogen, such as the required dose, time-course, and best route of administration for maximal benefits from estrogen treatment. The effects of estrogen on blood flow and cholesterol deposition similarly need further study. The elusive membrane receptors for estrogen should be explored further, to understand both their normal function and whether activation of these membrane receptors is neuroprotective. Why do exogenous, but not endogenous, steroids protect (as demonstrated by some castration experiments showing that castration does not alter responses to lesion (e.g. Kujawa and Jones, 1991; Kujawa et al., 1993). Jones and colleagues (Jones et al., 2000) have argued that one mechanism for steroid induced neuroprotection involves the heat shock proteins, which form part of the steroid receptor heteromeric complex in the ligand-free state. They argue that when ligand causes the dissociation of heat shock proteins from the receptor complex, the pool of liberated heat shock protein can initiate signaling cascades that accelerate regenerative responses following 
injury; similar mechanisms have been invoked by Toran-Allerand et al. (1999). Thus, exogenous steroid exposure may eliminate the need for de novo synthesis of heat shock protein in response to injury. Studies to overexpress heat shock proteins following injury may answer this question.

Much remains to be learned about the regulation of the nuclear estrogen receptors in the nervous system, such as how expression of these receptors is altered by cyclical and maturational shifts in hormones, pregnancy hormones, environmental cues, nutritional status, and behaviors as well as by neural disease or trauma. For those neuroprotectve effects that are dependent on estrogen receptors, how are these receptors regulated following damage? Is their regulation specific to the type of damage incurred? Is recent exposure to estrogen necessary to maintain estrogen senstivity, such that acute estrogen treatment will not sustain survival mechanisms in elderly women because their estrogen receptor concentrations are too low? Are sex differences in mental and neurological disorders correlated in some way with disturbances of steroid receptor expressing areas specifically? What neurotransmitters regulate expression of estrogen receptors, and do declines in specific neurotransmitters, for example, serotonin, affect responses to estrogen? Which specific coactivators or adapter proteins are expressed in the nervous system and can their expression and regulation be manipulated to enhance the neuroprotective effects of estrogen? Finally, the extent to which sex differences in developmental exposure to steroid hormones alters responses to the protective effects of estrogen in adulthood is unknown.

\subsection{Optimal estrogen administration in neuroprotection}

Clinically, what is the time course of estrogen exposure required to promote protection? If very high doses are necessary, are acute treatments sufficient? What is the effective window of time available to treat patients with acute lesions, or does the hormone need to be present at the time of injury to protect the brain? Is exogenously delivered estrogen as effective as endogenously formed hormone, and is it preferable, in terms of protection of the brain and protection from side effects, to administer a large, acute bolus of testosterone, and let the brain do the work of selecting the site for local synthesis of estrogen? Clearly, there are many questions to be addressed in future investigations on the clinical efficacy of estrogen in treatment of neurological diseases and injury.

\section{Concluding remarks}

Neuroprotection by estrogen holds great promise for improving the clinical management of selected neurodegenerative diseases and neural trauma. Under normal conditions, estrogen has diverse pleiotropic effects on the nervous system, beyond those effects that constitute essential components of hypothalamo-pituitarygonadal regulation or the control of reproductive behaviors. Similarly, the neuroprotective effects of estrogen might be expected to be diverse and broad-ranging. The balance between protective and toxic levels of estrogen may be lesion, region, and age-dependent, and should be carefully investigated. The opposing developmental effects of estrogen, promoting survival in some cell populations and death in others, and the negative impact of high levels of estrogen on survival in aging neuronal populations, are powerful reminders that caution must be used in predicting and exploiting the potential therapeutically beneficial effects of estrogen on the nervous system.

\section{Note added in proof}

Since this review was prepared, two reports have been published that call into question the therapeutic use of estrogen in symptomatic Alzheimer's disease (Henderson et al., 2000; Mulnard et al., 2000). These reports detail the results of separate randomized, double-blind, placebo-controlled clinical studies designed to test the potential of estrogen as a therapeutic agent in mild to moderate Alzheimer's disease patients. Although the length of treatment with conjugated equine estrogens was different in the two studies (4 or 16 weeks in the Henderson et al., study, and 1 year in the Mulnard et al., study) the results were similar: estrogen treatment did not prevent cognitive decline in women with mild to moderate Alzheimer's disease. In fact, estrogen treatment for 1 year was associated with a worsening of symptoms in these patients. These findings agree with experimental data indicating that estrogen is neuroprotective when administered before or at the same time as the neurodegenerative stimulus but is not neuroprotective when administered after the neurodegenerative stimulus. In conclusion, both clinical and experimental data suggest that estrogen may act as a preventive agent for neurodegeneration, while the hormone is probably unable to act as a restorative agent in already degenerated neural tissue.

\section{Acknowledgements}

The authors wish to express their appreciation to the following: Dr. Fred Naftolin; Drs. Nancy Muma and Kathryn Jones for comments on the manuscript; Ms. Kristin Gatto and Ms. Virginia Hayes for assist- 
ance with the references. LLDC was supported by a research leave fellowship from Loyola University Chicago. LMG-S and IA were supported by DGESIC (grant nr. PM98-0110).

\section{References}

Adan, R.A., Cox, J.J., Beischlag, T.V., Burbach, J.P., 1993. A composite hormone response element mediates the transactivation of the rat oxytocin gene by different classes of nuclear hormone receptors. Mol. Endocrinol. 7, 47-57.

Agrati, P., Garnier, M., Patrone, C., Pollio, G., Santagati, S., Vegeto, E., Maggi, A., 1997. SK-ER3 neuroblastoma cells as a model for the study of estrogen influence on neural cells. Brain Res. Bull. 44, 519-523.

Alkayed, N.J., Harukuni, I., Kimes, A.S., London, E.D., Traystman, R.J., Hurn, P.D., 1998. Gender-linked brain injury in experimental stroke. Stroke 29, 159-165.

Altman, J., Das, G.D., 1965. Autoradiographic and histological evidence of postnatal hippocampal neurogenesis in rats. J. Comp. Neurol. 124, 319-335.

Alvarez-Buylla, A., Kirn, J.R., 1997. Birth, migration, incorporation, and death of vocal control neurons in adult songbirds. $J$. Neurobiol. 33, 585-601.

Alvarez-Buylla, A., Lois, C., 1995. Neuronal stem cells in the brain of adult vertebrates. Stem Cells 33, 263-272.

Arai, Y., Sekine, Y., Murakami, S., 1996. Estrogen and apoptosis in the developing sexually dimorphic preoptic area in female rats. Neurosci. Res. 25, 403-407.

Arimatsu, Y., Hatanaka, H., 1986. Estrogen treatment enhances survival of cultured fetal rat amygdala neurons in a defined medium. Dev. Brain Res. 26, 151-159.

Asbury, E.T., Fritts, M.E., Horton, J.E., Isaac, W.L., 1998. Progesterone facilitates the acquisition of avoidance learning and protects against subcortical neuronal death following prefrontal cortex ablation in the rat. Behav. Brain Res. 97, 99-106.

Asthana, S., Craft, S., Baker, L.D., Raskind, M.A., Birnbaum, R.S., Lofgreen, C.P., Veith, R.C., Plymate, S.R., 1999. Cognitive and neuroendocrine response to transdermal estrogen in postmenopausal women with Alzheimer's disease: results of a placebo-controlled, double-blind, pilot study. Psychoneuroendocrinology 24, 657-677.

Aumais, J.P., Lee, H.S., Degannes, C., Horsord, J., White, J.H., 1996. Function of directly repeated half-sites as response elements for steroid-hormone receptors. J. Biol. Chem. 271, 12568-12577.

Azcoitia, I., Sierra, A., Garcia-Segura, L.M., 1998. Estradiol prevents kainic acid-induced neuronal loss in the rat dentate gyrus. NeuroReport 9, 3075-3079.

Azcoitia, I., Fernandez-Galaz, M.C., Sierra, A., Garcia-Segura, L.M., 1999a. Gonadal hormones affect neuronal vulnerability to excitotoxin-induced degeneration. J. Neurocytol. 28, 699-710.

Azcoitia, I., Sierra, A., Garcia-Segura, L.M., 1999b. Neuroprotective effects of estradiol in the adult rat hippocampus: interaction with insulin-like growth factor-I signalling. J. Neurosci. Res. 58, 815822.

Azcoitia, I., Sierra, A., Garcia-Segura, L.M., 1999c. Localization of estrogen receptor $\beta$-immunoreactivity in astrocytes of the adult rat brain. Glia 26, 260-267.

Bale, T.L., Dorsa, D.M., 1997. Cloning, novel promoter sequence, and estrogen regulation of a rat oxytocin receptor gene. Endocrinology 138, 1151-1158.

Bales, K.R., Verina, T., Cummins, D.J., Du, Y., Dodel, R.C., Saura, J., Fishman, C.E., DeLong, C.A., Piccardo, P., Petegnief, V., Ghetti, B., Paul, S.M., 1999. Apolipoprotein E is essential for amyloid deposition in the APP(V717F) transgenic mouse model of Alzheimer's disease. Proc. Natl. Acad. Sci. USA 96, 1152311528.

Balthazart, J., Ball, G.F., 1998. New insights into the regulation and function of brain estrogen synthase (aromatase). Trends Neurosci. 21, 243-249.

Barnea, A., Nottebohm, F., 1994. Seasonal recruitment of hippocampal neurons in adult free-ranging black-capped chickadees. Proc. Natl. Acad. Sci. USA 91, 11217-11221.

Baskin, D.S., Browning, J.L., Pirozzolo, F.J., Korporaal, S., Baskin, J.A., Appel, S.H., 1999. Brain choline acetyltransferase and mental function in Alzheimer disease. Arch. Neurol. 56, 1121-1123.

Beck, K.D., Powell-Braxton, L., Widmer, H.R., Valverde, J., Hefti, F., 1995. Igfl gene disruption results in reduced brain size, CNS hypomyelination, and loss of hippocampal granule and striatal parvalbumin-containing neurons. Neuron. 14, 717-730.

Becker, J.B., 1999. Gender differences in dopaminergic function in striatum and nucleus accumbens. Pharmacol. Biochem. Behav. 64, 803-812.

Behl, C., 1999. Alzheimer's disease and oxidative stress: implications for novel therapeutic approaches. Prog. Neurobiol. 57, 301-323.

Behl, C., Holsboer, F., 1999. The female sex hormone oestrogen as a neuroprotectant. Trends Pharmacol. Sci. 20, 441-444.

Behl, C., Manthey, D., 2000. Neuroprotective activities of estrogen: an update. J. Neurocytol., in press.

Behl, C., Widmann, M., Trapp, T., Holsboer, F., 1995. $17 \beta$ Estradiol protects neurons from oxidative stress-induced cell death in vitro. Biochem. Biophys. Res. Commun. 216, 473-482.

Behl, C., Skutella, T., Lezoualch, F., Post, A., Widmann, M., Newton, C.J., Holsboer, F., 1997. Neuroprotection against oxidative stress by estrogens: structure-activity relationship. Mol. Pharmacol. 51, 535-541.

Bethea, C.L., Fahrenbach, W.H., Sprangers, S.A., Freesh, F., 1992. Immunocytochemical localization of progestin receptors in monkey hypothalamus: effect of estrogen and progestin. Endocrinology 130, 895-905.

Beyer, C., Raab, H., 1998. Nongenomic effects of oestrogen: embryonic mouse midbrain neurones respond with a rapid release of calcium from intracellular stores. Eur. J. Neurosci. 10, 255-262.

Bicknell, R.J., 1998. Sex-steroid actions on neurotransmission. Curr. Opin. Neurol. 11, 667-671.

Bimonte, H.A., Denenberg, V.H., 1999. Estradiol facilitates performance as working memory load increases. Psychoneuroendocrinology 24, 161-173.

Blaustein, J.D., King, J.C., Toft, D.O., Turcotte, J., 1988. Immunocytochemical localization of estrogen-induced progestin receptors in guinea pig brain. Brain Res. 474, 1-15.

Blaustein, J.D., Lehman, M.N., Turcotte, J.C., Greene, G., 1992. Estrogen receptors in dendrites and axon terminals in the guinea pig hypothalamus. Endocrinology 131, 281-290.

Blurton-Jones, M.M., Roberts, J.A., Tuszynski, M.H., 1999. Estrogen receptor immunoreactivity in the adult primate brain: neuronaldistribution and association with p75, trkA, and choline acetyltransferase. J. Comp. Neurol. 405, 529-542.

Bogdanov, M.B., Ferrante, R.J., Mueller, G., Ramos, L.E., Martinou, J.C., Beal, M.F., 1999. Oxidative stress is attenuated in mice overexpressing BCL-2. Neurosci. Lett. 262, 33-36.

Bonnefont, A.B., Munoz, F.J., Inestrosa, N.C., 1998. Estrogen protects neuronal cells from the cytotoxicity induced by acetylcholinesterase-amyloid complexes. FEBS Lett. 441, 220-224.

Brandi, M.L., Becherini, L., Gennari, L., Racchi, M., Bianchetti, A., Nacmias, B., Sorbi, S., Mecocci, P., Senin, U., Govoni, S., 1999. Association of the ER- $\alpha$ gene polymorphisms with sporadic Alzheimer's disease. Biochem. Biophys. Res. Commun. 265, 335338.

Brawer, J.R., Naftolin, F., Martin, J., Sonnenschein, C., 1978. Effects of a single injection of estradiol valerate on the hypothala- 
mic arcuate nucleus and on reproductive function in the female rat. Endocrinology 103, 501-512.

Brinton, R.D., Tran, J., Proffitt, P., Montoya, M., 1997. 17ßEstradiol enhances the outgrowth and survival of neocortical neurons in culture. Neurochem. Res. 22, 1339-1351.

Brown, S.D., Johnson, F., Bottjerm, S.W., 1993. Neurogenesis in adult canary telencephalon is independent of gonadal hormone levels. J. Neurosci. 13, 2024-2032.

Burek, M.J., Nordeen, K.W., Nordeen, E.J., 1995. Estrogen promotes neuron addition to an avian song-control nucleus by regulating post-mitotic events. Dev. Brain Res. 85, 220-224.

Burgess, C.E., Lindblad, K., Sidransky, E., Yuan, Q.P., Long, R.T., Breschel, T., Ross, C.A., McInnis, M., Lee, P., Ginns, E.I., Lenane, M., Kumra, S., Jacobsen, L., Rapoport, J.L., Schalling, M., 1998. Large CAG/CTG repeats are associated with childhood-onset schizophrenia. Mol. Psychiatry 3, 321-327.

Calderon, F.H., Bonnefont, A., Munoz, F.J., Fernandez, V., Videla, L.A., Inestrosa, N.C., 1999. PC12 and neuro 2a cells have different susceptibilities to acetylcholinesterase-amyloid complexes, amyloid 25-35 fragment, glutamate, and hydrogen peroxide. J. Neurosci. Res. 56, 620-631.

Callier, S., Morisette, M., Grandbois, M., Di Paolo, T., 2000. Stereospecific prevention by $17 \beta$-Estradiol of MPTP-induced dopamine depletion in mice. Synapse, in press.

Cameron, H.A., McKay, R.D., 1999. Restoring production of hippocampal neurons in old age. Nat. Neurosci. 2, 894-897.

Canuso, C.M., Goldstein, J.M., Green, A.I., 1998. The evaluation of women with schizophrenia. Psychopharmacol. Bull. 34, 271-277.

Celotti, F., Negri-Cesi, P., Poletti, A., 1997. Steroid metabolism in the mammalian brain: $5 \alpha$-reduction and aromatization. Brain Res. Bull. 44, 365-375.

Cerillo, G., Reesm, A., Manchanda, N., Reilly, C., Brogan, I., White, A., Needham, M., 1998. The oestrogen receptor regulates NF- $\mathrm{KB}$ and AP-1 activity in a cell-specific manner. J. Steroid Biochem. Mol. Biol. 67, 79-88.

Chan, S.L., Tammariello, S.P., Estus, S., Mattson, M.P., 1999. Prostate apoptosis response-4 mediates trophic factor withdrawalinduced apoptosis of hippocampal neurons: actions prior to mitochondrial dysfunction and caspase activation. J. Neurochem. 73, 502-512.

Chang, C.L., Donaghy, M., Poulter, N., 1996. Migraine and stroke in young women: case-control study. The World Health Organisation Collaborative Study of Cardiovascular Disease and Steroid Hormone Contraception. BMJ 318, 13-18.

Chang, D., Kwan, J., Timiras, P.S., 1997. Estrogens influence growth, maturation, and amyloid $\beta$-peptide production in neuroblastoma cells and in a $\beta$-APP transfected kidney 293 cell line. Adv. Exp. Med. Biol. 429, 261-271.

Chen, D.F., Schneider, G.E., Martinou, J.C., Tonegawa, S., 1997a. $\mathrm{Bcl}-2$ promotes regeneration of severed axons in mammalian CNS. Nature 385, 434-439.

Chen, J., Adachi, N., Liu, K., Arai, T., 1998. The effects of 17ßEstradiol on ischemia-induced neuronal damage in the gerbil hippocampus. Neuroscience 87, 817-822.

Chen, Y., Lomnitski, L., Michaelson, D.M., Shohami, E., 1997b. Motor and cognitive deficits in apolipoprotein E-deficient mice after closed head injury. Neuroscience 80, 1255-1262.

Cheng, H.L., Feldman, E.L., 1998. Bidirectional regulation of p38 kinase and c-Jun N-terminal protein kinase by insulin-like growth factor-I. J. Biol. Chem. 273, 14560-14565.

Chowen, J.A., Torres-Aleman, I., Garcia-Segura, L.M., 1992. Trophic effects of estradiol on fetal rat hypothalamic neurons. Neuroendocrinology 56, 895-901.

Clark, A.S., Nock, B., Feder, H.H., Roy, E.J., 1985. $\alpha$ 1-noradrenergic receptor blockade decreases nuclear estrogen receptor binding in guinea pig hypothalamus and preoptic area. Brain Res. 330, 197-199.
Corness, J.D., Burbach, J.P., Hokfelt, T., 1997. The rat galanin-gene promoter: response to members of the nuclear hormone receptor family, phorbol ester and forskolin. Mol. Brain Res. 47, 11-23.

Costa, M.M., Reus, V.I., Wolkowitz, O.M., Manfredi, F., Lieberman, M., 1999. Estrogen replacement therapy and cognitive decline in memory-impaired post-menopausal women. Biol. Psychiatry 46, 182-188.

Cowley, S.M., Hoare, S., Mosselman, S., Parker, M.G., 1997. Estrogen receptors alpha and beta form heterodimers on DNA. J. Biol. Chem. 272, 19858-19862.

Culmsee, C., Vedder, H., Ravati, A., Junker, V., Otto, D., Ahlemeyer, B., Krieg, J.C., Krieglstein, J., 1999. Neuroprotection by estrogens in a mouse model of focal cerebral ischemia and in cultured neurons: evidence for a receptor-independent antioxidative mechanism. J. Cereb. Blood Flow Metab. 19, 1263-1269.

Davis, E.C., Popper, P., Gorski, R.A., 1996. The role of apoptosis in sexual differentiation of the rat sexually dimorphic nucleus of the preoptic area. Brain Res. 734, 10-18.

de Chaves, E.I., Rusinol, A.E., Vance, D.E., Campenot, R.B., Vance, J.E., 1997. Role of lipoproteins in the delivery of lipids to axons during axonal regeneration. J. Biol. Chem. 272, 3076630773.

De Pablo, F., De la Rosa, E.J., 1995. The developing CNS: a scenario for the action of proinsulin, insulin and insulin-like growth factors. Trends Neurosci. 18, 143-150.

Desjardins, G.C., Beaudet, A., Meaney, M.J., Brawer, J.R., 1995. Estrogen-induced hypothalamic $\beta$-endorphin neuron loss: a possible model of hypothalamic aging. Exp. Gerontol. 30, 253-267.

Diaz, H., Lorenzo, A., Carrer, H.F., Caceres, A., 1992. Time lapse study of neurite growth in hypothalamic dissociated neurons in culture: sex differences and estrogen effects. J. Neurosci. Res. 33, 266-281.

Di Paolo, T., 1994. Modulation of brain dopamine transmission by sex steroids. Rev. Neurosci. 5, $27-41$.

Disshon, K.A., Dluzen, D.E., 1997. Estrogen as a neuromodulator of MPTP-induced neurotoxicity: effects upon striatal dopamine release. Brain Res. 764, 9-16.

Disshon, K.A., Boja, J.W., Dluzen, D.E., 1998. Inhibition of striatal dopamine transporter activity by $17 \beta$-Estradiol. Eur. J. Pharmacol. 345, 207-211.

Dluzen, D.E., 1997. Estrogen decreases corpus striatal neurotoxicity in response to 6-hydroxydopamine. Brain Res. 767, 340-344.

Dluzen, D.E., 2000. Neuroprotective effects of estrogen upon the nigrostriatal dopaminergic system. J. Neurocytol., in press.

Dluzen, D.E., McDermott, J.L., Liu, B., 1996a. Estrogen as a neuroprotectant against MPTP-induced neurotoxicity in C57/B1 mice. Neurotoxicol. Teratol. 18, 603-606.

Dluzen, D.E., McDermott, J.L., Liu, B., 1996b. Estrogen alters MPTP-induced neurotoxicity in female mice: effects on striatal dopamine concentrations and release. J. Neurochem. 66, 658-666.

Dodel, R.C., Du, Y., Bales, K.R., Gao, F., Paul, S.M., 1999. Sodium salicylate and $17 \beta$-Estradiol attenuate nuclear transcription factor NF- $\mathrm{KB}$ translocation in cultured rat astroglial cultures following exposure to amyloid A $\beta(1-40)$ and lipopolysaccharides. J. Neurochem. 73, 1453-1460.

Dohler, K.D., Coquelin, A., Davis, F., Hines, M., Shryne, J.E., Gorski, R.A., 1984. Pre- and post-natal influence of testosterone propionate and diethylstilbestrol on differentiation of the sexually dimorphic nucleus of the preoptic area in male and female rats. Brain Res. 302, 291-295.

Donaghue, C., Westley, B.R., May, F.E., 1999. Selective promoter usage of the human estrogen receptor- $\alpha$ gene and its regulation by estrogen. Mol. Endocrinology 13, 1934-1950.

DonCarlos, L.L., Handa, R.J., 1994. Developmental profile of estrogen receptor mRNA in the preoptic area of male and female neonatal rats. Dev. Brain Res. 79, 283-289.

DonCarlos, L.L., Greene, G.L., Morrell, J.I., 1989. Estrogen plus 
progesterone increases progestin receptor immunoreactivity in the brain of ovariectomized guinea pigs. Neuroendocrinology 50, 613-623.

DonCarlos, L.L., Monroy, E., Morrell, J.I., 1991. Distribution of estrogen receptor-immunoreactive cells in the forebrain of the female guinea pig. J. Comp. Neurol. 305, 591-612.

DonCarlos, L.L., McAbee, M., Ramer-Quinn, D.S., Stancik, D.M., 1995. Estrogen receptor mRNA levels in the preoptic area of neonatal rats are responsive to hormone manipulation. Dev. Brain Res. 84, 253-260.

Duan, W., Rangnekar, V.M., Mattson, M.P., 1999a. Prostate apoptosis response-4 production in synaptic compartments following apoptotic and excitotoxic insults: evidence for a pivotal role in mitochondrial dysfunction and neuronal degeneration. J. Neurochem. 72, 2312-2322.

Duan, W., Zhang, Z., Gash, D.M., Mattson, M.P., 1999 b. Participation of prostate apoptosis response-4 in degeneration of dopaminergic neurons in models of Parkinson's disease. Ann. Neurol. 46, 587-597.

Dubal, D.B., Kashon, M.L., Pettigrew, L.C., Ren, J.M., Finklestein, S.P., Rau, S.W., Wise, P.M., 1998. Estradiol protects against ischemic injury. J. Cereb. Blood Flow Metab. 18, 1253-1258.

Dubal, D.B., Shughrue, P.J., Wilson, M.E., Merchenthaler, I., Wise, P.M., 1999. Estradiol modulates bcl-2 in cerebral ischemia: a potential role for estrogen receptors. J. Neurosci. 19, 6385-6393.

Dubik, D., Shiu, R.P., 1992. Mechanism of estrogen activation of cmyc oncogene expression. Oncogene 7, 1587-1594.

Duenas, M., Torres-Aleman, I., Naftolin, F., Garcia-Segura, L.M., 1996. Interaction of insulin-like growth factor-1 and estradiol signaling pathways on hypothalamic neuronal differentiation. Neuroscience 74, 531-539.

El-Ashry, D., Chrysogelos, S.A., Lippman, M.E., Kern, F.G., 1996. Estrogen induction of TGF- $\alpha$ is mediated by an estrogen response element composed of two imperfect palindromes. J. Steroid Biochem. Mol. Biol. 59, 261-269.

Fader, A.J., Johnson, P.E., Dohanich, G.P., 1999. Estrogen improves working but not reference memory and prevents amnestic effects of scopolamine of a radial-arm maze. Pharmacol. Biochem. Behav. 62, 711-717.

Faivre-Bauman, A., Rosenbaum, E., Puymirat, J., Grouselle, D., Tixier-Vidal, A., 1981. Differentiation of fetal mouse hypothalamic cells in serum-free medium. Dev. Neurosci. 4, 118-129.

Falkeborn, M., Persson, I., Terent, A., Adami, H.O., Lithell, H., Bergstrom, R., 1993. Hormone replacement therapy and the risk of stroke. Follow-up of a population-based cohort in Sweden. Arch. Intern. Med. 153, 1201-1209.

Fernandez, A.M., Gonzalez de la Vega, A., Planas, B., TorresAleman, I., 1999. Neuroprotective actions of peripherally administered insulin-like growth factor I in the injured olivo-cerebellar pathway. Eur. J. Neurosci. 11, 2019-2030.

Fernandez-Galaz, M.C., Morschl, E., Chowen, J.A., Torres-Aleman, I., Naftolin, F., Garcia-Segura, L.M., 1997. Role of astroglia and insulin-like growth factor-I in gonadal hormone dependent synaptic plasticity. Brain Res. Bull. 44, 525-531.

Fernandez-Galaz, M.C., Naftolin, F., Garcia-Segura, L.M., 1999. Phasic synaptic remodeling in the rat arcuate nucleus during the estrous cycle depends on insulin like growth factor-I receptor activation. J. Neurosci. Res. 55, 286-292.

Ferreira, A., Caceres, A., 1991. Estrogen-enhanced neurite growth: evidence for a selective induction of Tau and stable microtubules. J. Neurosci. 11, 392-400.

Fillit, H., Weinreb, H., Cholst, I., Luine, V., McEwen, B., Amador, R., Zabriskie, J., 1986. Observations in a preliminary open trial of estradiol therapy for senile dementia-Alzheimer's type. Psychoneuroendocrinology 11, 337-345.

Finley, S.K., Kritzer, M.F., 1999. Immunoreactivity for intracellular androgen receptors in identified subpopulations of neurons, astro- cytes and oligodendrocytes in primate prefrontal cortex. J. Neurobiol. 40, 446-457.

Foy, M.R., Chiaia, N.L., Teyler, T.J., 1984. Reversal of hippocampal sexual dimorphism by gonadal steroid manipulation. Brain Res. 321, 311-314.

Frick, K.M., Burlingame, L.A., Arters, J.A., Berger-Sweeney, J., 2000. Reference memory, anxiety and estrous cyclicity in C57BL/ 6NIA mice are affected by age and sex. Neuroscience 95, 293307.

Gail, M.H., Costantino, J.P., Bryant, J., Croyle, R., Freedman, L., Helzlsouer, K., Vogel, V., 1999. Weighing the risks and benefits of tamoxifen treatment for preventing breast cancer. J. Natl. Cancer Inst. 91, 1829-1846.

Ganter, S., Northoff, H., Mannel, D., Gebicke-Harter, P.J., 1992. Growth control of cultured microglia. J. Neurosci. Res. 33, 218 230.

Garcia, M., Westley, B., Rochefort, H., 1981. 5-Bromodeoxyuridine specifically inhibits the synthesis of estrogen-induced proteins in MCF7 cells. Eur. J. Biochem. 116, 297-301.

Garcia-Estrada, J., del Rio, J.A., Luquin, S., Soriano, E., GarciaSegura, L.M., 1993. Gonadal hormones down-regulate reactive gliosis and astrocyte proliferation after a penetrating brain injury. Brain Res. 628, 271-278.

Garcia-Estrada, J., Luquin, S., Fernandez, A., Garcia-Segura, L.M., 1999. Dehydroepiandrosterone, pregnenolone and sex steroids down-regulate reactive astroglia in the male rat brain after a penetrating brain injury. Int. J. Devl. Neurosci. 17, 145-151.

Garcia-Segura, L.M., Chowen, J.A., Parducz, A., Naftolin, F., 1994. Gonadal hormones as promoters of structural synaptic plasticity: cellular mechanisms. Prog. Neurobiol. 44, 279-307.

Garcia-Segura, L.M., Chowen, J.A., Naftolin, F., 1996. Endocrine glia: role of glial cells in the brain actions of steroid and thyroid hormones and in the regulation of hormone secretion. Front. Neuroendocrinol. 17, 180-211.

Garcia-Segura, L.M., Cardona-Gomez, P., Naftolin, F., Chowen, J.A., 1998. Estradiol upregulates Bcl-2 expression in adult brain neurons. NeuroReport 9, 593-597.

Garcia-Segura, L.M., Naftolin, F., Hutchison, J.B., Azcoitia, I., Chowen, J.A., 1999a. Role of astroglia in estrogen regulation of synaptic plasticity and brain repair. J. Neurobiol. 40, 574-584.

Garcia-Segura, L.M., Wozniack, A., Azcoitia, I., Rodriguez, J.R., Hutchison, R.E., Hutchison, J.B., 1999b. Aromatase expression by astrocytes after brain injury: implications for local estrogen formation in brain repair. Neuroscience 89, 567-578.

Garnier, M., Di Lorenzo, D., Albertini, A., Maggi, A., 1997. Identification of estrogen-responsive genes in neuroblastoma SKER3 cells. J. Neurosci. 17, 4591-4599.

Gee, A.C., Carlson, K.E., Martinin, P.G.V., Katzenellenbogen, B.S., Katzenellenbogen, J.A., 1999. Coactivator peptides have a differential stabilizing effect on the binding of estrogens and antiestrogens with the estrogen receptor. Mol. Endocrinol. 13, 1912-1923.

Gibbs, R.B., 1999. Treatment with estrogen and progesterone affects relative levels of brain-derived neurotrophic factor mRNA and protein in different regions of the adult rat brain. Brain Res. 844, 20-27.

Gibbs, R.B., Wu, D., Hersh, L.B., Pfaff, D.W., 1994. Effects of estrogen replacement on the relative levels of choline acetyltransferase, trkA, and nerve growth factor messenger RNAs in the basal forebrain and hippocampal formation of adult rats. Exp. Neurol. 129, 70-80.

Gold, B.G., Densmore, V., Shou, W., Matzuk, M.M., Gordon, H.S., 1999. Immunophilin FK506-binding protein 52 (not FK506-binding protein 12) mediates the neurotrophic action of FK506. J. Pharmacol. Exp. Ther. 289, 1202-1210.

Goldman, S.A., 1998. Adult neurogenesis: from canaries to the clinic. J. Neurobiol. 36, 267-286.

Goldstein, J.M., Seidman, L.J., Goodman, J.M., Koren, D., Lee, H., 
Weintraub, S., Tsuang, M.T., 1998. Are there sex differences in neuropsychological functions among patients with schizophrenia? Am. J. Psychiatry 155, 1358-1364.

Gollapudi, L., Oblinger, M.M., 1999a. Stable transfection of PC12 cells with estrogen receptor $\left(\mathrm{ER}_{\alpha}\right)$ : protective effects of estrogen on cell survival after serum deprivation. J. Neurosci. Res. 56, 99108.

Gollapudi, L., Oblinger, M.M., 1999b. Estrogen and NGF synergistically protect terminally differentiated, $\mathrm{ER}_{\alpha}$-transfected $\mathrm{PC} 12$ cells from apoptosis. J. Neurosci. Res. 56, 471-481.

Gomez-Mancilla, B., Bedard, P.J., 1992. Effect of estrogen and progesterone on L-dopa induced dyskinesia in MPTP-treated monkeys. Neurosci. Lett. 135, 129-132.

Gonzalez-Vidal, M.D., Cervera-Gaviria, M., Ruelas, R., Escobar, A., Morali, G., Cervantes, M., 1998. Progesterone: protective effects on the cat hippocampal neuronal damage due to acute global cerebral ischemia. Arch. Med. Res. 29, 117-124.

Gould, E., Beylin, A., Tanapat, P., Reeves, A., Shors, T.J., 1999. Learning enhances adult neurogenesis in the hippocampal formation. Nat. Neurosci. 2, 260-265.

Gould, E., Cameron, H.A., Daniels, C., Woolley, C.S., McEwen, B.S., 1992. Adrenal hormones suppress cell division in the adult rat dentate gyrus. J. Neurosci. 12, 3642-3650.

Grandbois, M., Morisette, M., Callier, S., Di Paolo, T., 2000. Ovarian steroids and raloxifene prevent MPTP-induced dopamine depletion in mice. NeuroReport, in press.

Green, P.S., Bishop, J., Simpkins, J.W., 1997. 17 $\alpha$-Estradiol exerts neuroprotective effects on SK-N-SH cells. J. Neurosci. 17, 511515.

Green, P.S., Gridley, K.E., Simpkins, J.W., 1998. Nuclear estrogen receptor-independent neuroprotection by estratrienes: a novel interaction with glutathione. Neuroscience 84, 7-10.

Groswasser, Z., Cohen, M., Keren, O., 1998. Female TBI patients recover better than males. Brain Inj. 12, 805-808.

Gruzelier, J.H., 1994. Syndromes of schizophrenia and schizotypy, hemispheric imbalance and sex differences: implications for developmental psychopathology. Int. J. Psychophysiol. 18, 167-178.

Gudino-Cabrera, G., Nieto-Sampedro, M., 1999. Estrogen receptor immunoreactivity in Schwann-like brain macroglia. J. Neurobiol. 40, 458-470.

Guo, Q., Fu, W., Xie, J., Luo, H., Sells, S.F., Geddes, J.W., Bondada, V., Rangnekar, V.M., Mattson, M.P., 1998. Par-4 is a mediator of neuronal degeneration associated with the pathogenesis of Alzheimer disease. Nat. Med. 4, 957-962.

Hafner, H., Behrens, S., De Vry, J., Gattaz, W.F., 1991. An animal model for the effects of estradiol on dopamine-mediated behavior: implications for sex differences in schizophrenia. Psychiatry Res. 38, 125-134.

Hafner, H., Maurer, K., Loffler, W., van der Heiden, W., MunkJorgensen, P., Hambrecht, M., Riecher-Rossler, A., 1998. The ABC schizophrenia study: a preliminary overview of the results. Soc. Psychiatry Psychiatr. Epidemiol. 33, 380-386.

Halbreich, U., Rojansky, N., Palter, S., Tworek, H., Hissin, P., Wang, K., 1995. Estrogen augments serotonergic activity in postmenopausal women. Biol. Psychiatry 37, 434-441.

Handa, R.J., Reid, D.L., Resko, J.A., 1986. Androgen receptors in brain and pituitary of female rats: cyclic changes and comparisons with the male. Biol. Reprod. 34, 293-303.

Handa, R.J., Kerr, J.E., DonCarlos, L.L., McGivern, R.F., Hejna, G., 1996. Hormonal regulation of androgen receptor messenger RNA in the medial preoptic area of the male rat. Mol. Brain Res. 39, 57-67.

Hanstein, B., Liiu, H., Yaancisin, M.C., Brown, M., 1999. Functional analysis of a novel estrogen receptor-beta isoform. Mol. Endocrinol. 13, 129-137.

Hawk, T., Zhang, Y.Q., Rajakumar, G., Day, A.L., Simpkins, J.W., 1998. Testosterone increases and estradiol decreases middle cer- ebral artery occlusion lesion size in male rats. Brain Res. 796, 296-298.

Hayashi, S., 1994. Immunocytochemical detection of estrogen receptor in the facial nucleus of the newborn rat by three antibodies with distinct epitopes. Hormones and Behavior 28, 530-536.

Heck, S., Lezoualch, F., Engert, S., Behl, C., 1999. Insulin-like growth factor-1-mediated neuroprotection against oxidative stress is associated with activation of nuclear factor $\kappa \mathrm{B}$. J. Biol. Chem. 274, 9828-9835.

Henderson, A.S., Easteal, S., Jorm, A.F., Mackinnon, A.J., Korten, A.E., Christensen, H., Croft, L., Jacomb, P.A., 1995. Apolipoprotein E allele epsilon 4, dementia, and cognitive decline in a population sample. Lancet 346, 1387-1390.

Henderson, V.W., Paganini-Hill, A., Emanuel, C.K., Dunn, M.E., Buckwalter, J.G., 1994. Estrogen replacement therapy in older women. Comparisons between Alzheimer's disease cases and nondemented control subjects. Arch. Neurol. 51, 896-900.

Henderson, V.W., Paganini-Hill, A., Miller, B.L., Elble, R.J., Reyes, P.F., Shoupe, D., McCleary, C.A., Klein, R.A., Hake, A.M., Farlow, M.R., 2000. Estrogen for Alzheimer's disease in women: randomized, double-blind, placebo controlled trial. Neurology 54, 295-301.

Herbison, A.E., Augood, S.J., Simonian, S.X., Chapman, C., 1995. Regulation of GABA transporter activity and mRNA expression by estrogen in rat preoptic area. J. Neurosci. 15, 8302-8309.

Hidalgo, A., Barami, K., Iversen, K., Goldman, S.A., 1995. Estrogens and non-estrogenic ovarian influences combine to promote the recruitment and decrease the turnover of new neurons in the adult female canary brain. J. Neurobiol. 27, 470-487.

Hier, D.B., Yoon, W.B., Mohr, J.P., Price, T.R., Wolf, P.A., 1994. Gender and aphasia in the stroke data bank. Brain Lang. 47, 155-167.

Hoff, A.L., Wieneke, M., Faustman, W.O., Horon, R., Sakuma, M., Blankfeld, H., Espinoza, S., DeLisi, L.E., 1998. Sex differences in neuropsychological functioning of first-episode and chronically ill schizophrenic patients. Am. J. Psychiatry 155, 1437-1439.

Holm, K., Isacson, O., 1999. Factors intrinsic to the neuron can induce and maintain its ability to promote axonal outgrowth: a role for Bcl-2? Trends Neurosci. 22, 269-273.

Horsburgh, K., Kelly, S., McCulloch, J., Higgins, G.A., Roses, A.D., Nicoll, J.A., 1999. Increased neuronal damage in apolipoprotein E-deficient mice following global ischaemia. NeuroReport $10,837-841$.

Hortnagl, H., Hansen, L., Kindel, G., Schneider, B., el Tamer, A., Hanin, I., 1993. Sex differences and estrous cycle-variations in the AF64A-induced cholinergic deficit in the rat hippocampus. Brain Res. Bull. 31, 129-134.

Horwitz, K.B., Jackson, T.A., Bain, D.L., Richer, J.K., Takimoto, G.S., Tung, L., 1996. Nuclear receptor coactivators and corepressors. Mol. Endocrinol. 10, 1167-1177.

Hsieh Jr., Y.L., Hsu, C., Yang, S.L., Hsu, H.K., Peng, M.T., 1996. Estradiol modulation of neuron loss in the medial division of medial preoptic nucleus in rats during aging. Gerontology 42, 18-24.

Huang, L., DeVries, G.J., Bittman, E.L., 1998. Photoperiod regulates neuronal bromodeoxyuridine labeling in the brain of a seasonally breeding mammal. J. Neurobiol. 36, 410-420.

Huang, L., Laurence, J.M., Bittman, E.L., 1999. Cells generated in adulthood are activated during sexual behavior in male golden hamsters. Soc. Neuroscience Abst. 25, 72.

Hurn, P.D., Littleton-Kearney, M.T., Kirsch, J.R., Dharmarajan, A.M., Traystman, R.J., 1995. Postischemic cerebral blood flow recovery in the female: effect of $17 \beta$-Estradiol. J. Cereb. Blood Flow Metab. 15, 666-672.

Hutchison, J.B., Wozniak, A., Beyer, C., Karolczak, M., Hutchison, R.E., 1999. Steroid metabolising enzymes in the determination of brain gender. J. Steroid Biochem. Mol. Biol. 69, 85-96.

Ignatius, M.J., Gebicke-Harter, P.J., Skene, J.H., Schilling, J.W., 
Weisgraber, K.H., Mahley, R.W., Shooter, E.M., 1986. Expression of apolipoprotein E during nerve degeneration and regeneration. Proc. Natl. Acad. Sci. USA 83, 1125-1129.

Isoe-Wada, K., Maeda, M., Yong, J., Adachi, Y., Harada, H., Urakami, K., Nakashima, K., 1999. Positive association between an estrogen receptor gene polymorphism and Parkinson's disease with dementia. Eur. J. Neurol. 6, 431-435.

Jaffe, A.B., Toran-Allerand, C.D., Greengard, P., Gandy, S.E., 1994. Estrogen regulates metabolism of Alzheimer amyloid beta precursor protein. J. Biol. Chem. 269, 13065-13068.

Jones, K.J., 1993. Gonadal steroids as promoting factors in axonal regeneration. Brain Res. Bull. 30, 491-498.

Jones, K.J., Coers, S., Storer, P.D., Tanzer, L., Kinderman, N.B., 1999. Androgenic regulation of the central glia response following nerve damage. J. Neurobiol. 40, 560-573.

Jones, K.J., Alexander, T.D., Brown, T.J., Tanzer, L., 2000. Gonadal steroid enhancement of facial nerve regeneration: role of heat shock protein 70. J. Neurocytol., in press.

Jordan, C.L., 1999. Glia as mediators of steroid hormone action on the nervous system: an overview. J. Neurobiol. 40, 434-445.

Kaba, H., Rosser, A.E., Keverne, E.B., 1988. Hormonal enhancement of neurogenesis and its relationship to the duration of olfactory memory. Neuroscience $24,93-98$.

Kallos, J., Fasy, T.M., Hollander, V.P., Bick, M.D., 1978. Estrogen receptor has enhanced affinity for bromodeoxyuridine-substituted DNA. Proc. Natl. Acad. Sci. USA 75, 4896-4900.

Kaltschmidt, B., Uherek, M., Wellmann, H., Volk, B., Kaltschmidt, C., 1999. Inhibition of NF- $\mathrm{KB}$ potentiates amyloid beta-mediated neuronal apoptosis. Proc. Natl. Acad. Sci. USA 96, 9409-9414.

Kato, S., Tora, L., Yamauchi, J., Masushige, S., Bellard, M., Chambon, P., 1992. A far upstream estrogen response of the ovalbumin gene contains several half-palindromic 5'- TGACC'3' motifs acting synergistically. Cell 68, 731-742.

Keller, J.N., Germeyer, A., Begley, J.G., Mattson, M.P., 1997. 17ßEstradiol attenuates oxidative impairment of synaptic $\mathrm{Na}+/ \mathrm{K}+$ ATPase activity, glucose transport, and glutamate transport induced by amyloid beta-peptide and iron. J. Neurosci. Res. 50, 522-530.

Kelly, M.J., Lagrange, A.H., Wagner, E.J., Ronnekleiv, O.K., 1999. Rapid effects of estrogen to modulate $\mathrm{G}$ protein-coupled receptors via activation of protein kinase $\mathrm{A}$ and protein kinase $\mathrm{C}$ pathways. Steroids 64, 64-75.

Kempermann, G., Kuhn, H.G., Gage, F.H., 1997. More hippocampal neurons in adult mice living in an enriched environment. Nature 386, 493-495.

Kerr, J.E., Allore, R.J., Beck, S.G., Handa, R.J., 1995. Distribution and hormonal regulation of androgen receptor (AR) and AR messenger ribonucleic acid in the rat hippocampus. Endocrinology 136, 3213-3221.

Kertesz, A., Benke, T., 1989. Sex equality in intrahemispheric language organization. Brain Lang. 37, 401-408.

Kertesz, A., Sheppard, A., 1981. The epidemiology of aphasic and cognitive impairment in stroke: age, sex, aphasia type and laterality differences. Brain 104, 117-128.

Kinderman, N.B., Harrington, C.A., Drengler, S.M., Jones, K.J., 1998. Ribosomal RNA transcriptional activation and processing in hamster facial motoneurons: effects of axotomy with or without exposure to testosterone. J. Comp. Neurol. 401, 205-216.

Koenig, H.L., Schumacher, M., Ferzaz, B., Do Thi, A.N., Resouches, A., Guennoun, R., Jung-Testas, I., Robel, P., Akwa, Y., Baulieu, E.E., 1995. Progesterone synthesis and myelin formation by Schwann cells. Science 268, 1500-1503.

Kofler, B., Evans, H.F., Liu, M.L., Falls, V., Iismaa, T.P., Shine, J., Herzog, H., 1995. Characterization of the $5^{\prime}$-flanking region of the human preprogalanin gene. DNA Cell Biol. 14, 321-329.

Kolb, B., Pedersen, B., Ballermann, M., Gibb, R., Whishaw, I.Q., 1999. Embryonic and postnatal injections of bromodeoxyuridine produce age-dependent morphological and behavioral abnormalities. J. Neurosci. 19, 2337-2346.

Kruman, I.I., Pedersen, W.A., Springer, J.E., Mattson, M.P., 1999. ALS-linked $\mathrm{Cu} / \mathrm{Zn}$-SOD mutation increases vulnerability of motor neurons to excitotoxicity by a mechanism involving increased oxidative stress and perturbed calcium. Exp. Neurol. $160,28-39$.

Kuhn, H.G., Winkler, J., Kempermann, G., Thal, L.J., Gage, F.H., 1997. Epidermal growth factor and fibroblast growth factor-2 have different effects on neural progenitors in the adult rat brain. J. Neurosci. 17, 5820-5829.

Kuhnemann, S., Brown, T.J., Hochberg, R.B., MacLusky, N.J., 1994. Sex differences in the development of estrogen receptors in the rat brain. Horm. Behav. 28, 483-491.

Kuiper, G.G., Enmark, E., Pelto-Huikko, M., Nilsson, S., Gustafsson, J.A., 1996. Cloning of a novel receptor expressed in rat prostate and ovary. Proc. Natl. Acad. Sci. USA 93, 59255930.

Kujawa, K.A., Jones, K.J., 1991. Testosterone differentially regulates the regenerative properties of injured hamster facial motor neurons. J. Neurosci. 11, 3898-3906.

Kujawa, K.A., Jacob, J.M., Jones, K.J., 1993. Testosterone regulation of the regenerative properties of injured rat sciatic motor neurons. J. Neurosci. Res. 35, 268-273.

Lagrange, A.H., Wagner, E.J., Ronnekleiv, O.K., Kelly, M.J., 1996. Estrogen rapidly attenuates a $\mathrm{GABA}_{\mathrm{B}}$ response in hypothalamic neurons. Neuroendocrinology 64, 114-123.

Lagrange, A.H., Ronnekleiv, O.K., Kelly, M.J., 1997. Modulation of $\mathrm{G}$ protein-coupled receptors by an estrogen receptor that activates protein kinase A. Mol. Pharmacol. 51, 605-612.

Lamberts, S.W., van den Beld, A.W., van der Lely, A.J., 1997. The endocrinology of aging. Science 278, 419-424.

Langub, M.C., Watson, R.E., 1992. Estrogen receptor-immunoreactive glia, endothelia, and ependyma in guinea pig preoptic area and median eminence: electron microscopy. Endocrinology $130,364-372$.

Lannert, H., Wirtz, P., Schuhmann, V., Galmbacher, R., 1998. Effects of estradiol $(-17 \beta)$ on learning, memory and cerebral energy metabolism in male rats after intracerebroventricular administration of streptozotocin. J. Neural Transm. 105, 1045-1063.

Lauriello, J., Hoff, A., Wieneke, M.H., Blankfeld, H., Faustman, W.O., Rosenbloom, M., DeMent, S., Sullivan, E.V., Lim, K.O., Pfefferbaum, A., 1997. Similar extent of brain dysmorphology in severely ill women and men with schizophrenia. Am. J. Psychiatry 154, 819-825.

LeBlanc, A.C., Poduslo, J.F., 1990. Regulation of apolipoprotein E gene expression after injury of the rat sciatic nerve. J. Neurosci. Res. 25, 162-171.

Le Drean, Y., Lazennec, V., Kern, L., Saliguat, D., Pakdel, F., Valotaire, Y., 1995. Characterization of an estrogen-responsive element implicated in regulation of the rainbow trout estrogen receptor gene. J. Mol. Endocrinol. 15, 37-47.

Lee, J.H., Kim, J., Shapiro, D.H., 1995. Regulation of Xenopus-laevis estrogen receptor gene expression is mediated by an estrogen response element in the protein-coding region. DNA Cell Biol. $14,419-430$.

Lee, K., Richardson, C.D., Razik, M.A., Kwatra, M.M., Schwinn, D.A., 1998. Multiple potential regulatory elements in the $5^{\prime}$ flanking region of the human alpha 1a-adrenergic receptor. DNA Seq. $8,271-276$.

Lephart, E.D., 1996. A review of brain aromatase cytochrome P450. Brain Res. Rev. 22, 1-26.

Li, K., Futrell, N., Tovar, S., Wang, L.C., Wang, D.Z., Schultz, L.R., 1996. Gender influences the magnitude of the inflammatory response within embolic cerebral infarcts in young rats. Stroke 27, 498-503.

Li, H.Y., Wade, G.N., Blaustein, J.D., 1994. Manipulations of meta- 
bolic fuel availability alter estrous behavior and neural estrogen receptor immunoreactivity in Syrian hamsters. Endocrinology $135,240-247$.

Li, X., Schwartz, P.E., Rissman, E.F., 1997. Distribution of estrogen receptor-beta-like immunoreactivity in rat forebrain. Neuroendocrinology 66, 63-67.

Lindamer, L.A., Lohr, J.B., Harris, M.J., Jeste, D.V., 1997. Gender, estrogen, and schizophrenia. Psychopharmacol. Bull. 33, 221-228.

Lindamer, L.A., Lohr, J.B., Harris, M.J., McAdams, L.A., Jeste, D.V., 1999. Gender-related clinical differences in older patients with schizophrenia. J. Clin. Psychiatry 60, 61-67.

Longstreth, W.T., Nelson, L.M., Koepsell, T.D., van Belle, G., 1994. Subarachnoid hemorrhage and hormonal factors in women. A population-based case-control study. Ann. Intern. Med. 121, 168173.

Lorenzo, A., Diaz, H., Carrer, H., Caceres, A., 1992. Amygdala neurons in vitro: neurite growth and effects of estradiol. J. Neurosci. Res. 33, 418-435.

Luine, V.N., 1985. Estradiol increases choline acetyltransferase activity in specific basal forebrain nuclei and projection areas of female rats. Exp. Neurol. 89, 484-490.

Lustig, R.H., 1996. In vitro models for the effects of sex hormones on neurons. Ann. N. Y. Acad. Sci. 784, 370-380.

Lustig, R.H., Sudol, M., Pfaff, D.W., Federoff, H.J., 1991. Estrogenic regulation and sex dimorphism of growth-associated protein $43 \mathrm{kDa}(\mathrm{GAP}-43)$ messenger RNA in the rat. Mol. Brain Res. 11, 125-132.

Markowska, A.L., 1999. Sex dimorphism in the rate of age-related decline in spatial memory: relevance to alterations in the estrous cycle. J. Neurosci. 19, 8122-8133.

Matsumoto, A., 1991. Synaptogenic action of sex steroids in developing and adult neuroendocrine brain. Psychoneuroendocrinology 16, 25-40.

Matsumoto, A., Arai, Y., 1979. Synaptogenic effect of estrogen on the hypothalamic arcuate nucleus of the adult female rat. Cell. Tissue Res. 198, 427-433.

Matsumoto, A., Arai, Y., 1981. Neuronal plasticity in the deafferented hypothalamic arcuate nucleus of adult female rats and its enhancement by treatment with estrogen. J. Comp. Neurol. 197, 197-205.

Matsumoto, A., Arai, Y., Osanai, M., 1985. Estrogen stimulates neuronal plasticity in the deafferented hypothalamic arcuate nucleus in aged female rats. Neurosci. Res. 2, 412-418.

Mattson, M.P., Robinson, N., Guo, Q., 1997. Estrogens stabilize mitochondrial function and protect neural cells against the proapoptotic action of mutant presenilin-1. NeuroReport 8, 38173821.

McAbee, M.D., DonCarlos, L.L., 1998. Ontogeny of region-specific sex differences in androgen receptor messenger ribonucleic acid expression in the rat forebrain. Endocrinology 139, 1738-1745.

McAbee, M.D., DonCarlos, L.L., 1999a. Regulation of androgen receptor messenger ribonucleic acid expression in the developing rat forebrain. Endocrinology 140, 1807-1814.

McAbee, M.D., DonCarlos, L.L., 1999b. Estrogen, but not androgens, regulates androgen receptor messenger ribonucleic acid expression in the developing male rat forebrain. Endocrinology 140, 3674-3681.

McEwen, B.S., 1996. Gonadal and adrenal steroids regulate neurochemical and structural plasticity of the hippocampus via cellular mechanisms involving NMDA receptors. Cell Mol. Neurobiol. $16,103-116$.

McGlone, J., Losier, B.J., Black, S.E., 1997. Are there sex differences in hemispatial visual neglect after unilateral stroke? Neuropsychiatry Neuropsychol. Behav. Neurol. 10, 125-314.

McKay, L.I., Cidlowski, J.A., 1998. Cross-talk between nuclear factor- $\kappa$ B and the steroid hormone receptors: mechanisms of mutual antagonism. Mol. Endocrinol. 12, 45-56.
McMillan, P.J., Singer, C.A., Dorsa, D.M., 1996. The effects of ovariectomy and estrogen replacement on trkA and choline acetyltransferase mRNA expression in the basal forebrain of the adult female Sprague-Dawley rat. J. Neurosci. 16, 1860-1865.

McQueen, J.K., Wilson, H., Fink, G., 1997. Estradiol-17ß increases serotonin transporter (SERT) mRNA levels and the density of SERT-binding sites in female rat brain. Mol. Brain Res. 45, 1323.

Melcangi, R.C., Magnaghi, V., Martini, L., 1999. Steroid metabolism and effects in central and peripheral glial cells. J. Neurobiol. 40, 471-483.

Meltzer, C.C., Smith, G., DeKosky, S.T., Pollock, B.G., Mathis, C.A., Moore, R.Y., Kupfer, D.J., Reynolds, C.F., 1998. Serotonin in aging, late-life depression, and Alzheimer's disease: the emerging role of functional imaging. Neuropsychopharmacology, 18407-18430.

Mermelstein, P.G., Becker, J.B., Surmeier, D.J., 1996. Estradiol reduces calcium currents in rat neostriatal neurons via a membrane receptor. J. Neurosci. 16, 595-604.

Miller, D.B., Ali, S.F., O'Callaghan, J.P., Laws, S.C., 1998. The impact of gender and estrogen on striatal dopaminergic neurotoxicity. Ann. N. Y. Acad. Sci. 844, 153-165.

Miller, M., Hyder, S.M., Assayag, R., Panarella, S.R., Tousignant, P., Franklin, K.B., 1999. Estrogen modulates spontaneous alternation and the cholinergic phenotype in the basal forebrain. Neuroscience 91, 1143-1153.

Miranda, R.C., Sohrabji, F., Toran-Allerand, D., 1994. Interactions of estrogen with the neurotrophins and their receptors during neural development. Horm. Behav. 28, 367-375.

Miranda, R., Sohrabji, F., Singh, M., Toran-Allerand, D., 1996. Nerve growth factor (NGF) regulation of estrogen receptors in explant cultures of the developing forebrain. J. Neurobiol. 31, $77-87$.

Mong, J.A., McCarthy, M.M., 1999. Steroid-induced developmental plasticity in hypothalamic astrocytes: implications for synaptic pattering. J. Neurobiol. 40, 602-619.

Mook-Jung, I., Joo, I., Sohn, S., Kwon, H.J., Huh, K., Jung, M.W., 1997. Estrogen blocks neurotoxic effects of $\beta$-amyloid (1-42) and induces neurite extension on B103 cells. Neurosci. Lett. 235, 101104.

Moosmann, B., Behl, C., 1999. The antioxidant neuroprotective effects of estrogens and phenolic compounds are independent from their estrogenic properties. Proc. Natl. Acad. Sci. USA 96, 8867-8872.

Mor, G., Nilsen, J., Horvath, T., Bechmann, I., Brown, S., GarciaSegura, L.M., Naftolin, F., 1999. Estrogen and microglia: a regulatory system that affects the brain. J. Neurobiol. 40, 484-496.

Morrell, J.I., Pfaff, D.W., 1983. Immunocytochemistry of steroid hormone receiving cells in the central nervous system. Methods Enzymol. 103, 639-662.

Morrell, J.I., Krieger, M.S., Pfaff, D.W., 1986. Quantitative autoradiographic analysis of estradiol retention by cells in the preoptic area, hypothalamus and amygdala. Exp. Brain Res. 62, 343-354.

Morse, J.K., Scheff, S.W., DeKosky, S.T., 1986. Gonadal steroids influence axon sprouting in the hippocampal dentate gyrus: a sexually dimorphic response. Exp. Neurol. 94, 649-658.

Morse, J.K., DeKosky, S.T., Scheff, S.W., 1992. Neurotrophic effects of steroids on lesion-induced growth in the hippocampus. II. Hormone Replacement. Exp. Neurol. 118, 47-52.

Moss, R.L., Gu, Q., 1999. Estrogen: mechanisms for a rapid action in CA1 hippocampal neurons. Steroids 64, 14-21.

Moss, R.L., Gu, Q., Wong, M., 1997. Estrogen: nontranscriptional signaling pathway. Recent Prog. Horm. Res. 52, 33-68.

Mulnard, R.A., Cooman, C.W., Kawas, C., vanDyck, C.H., Sano, M., Doody, R., Koss, E., Pfeiffer, E., Jin, S., Gamst, A., Grundman, M., Thomas, R., Thal, L.J., 2000. Estrogen replacement therapy for treatment of mild to moderate Alzhiemers dis- 
ease: a randomized controlled trial. Alzheimer's Disease Cooperative Study. JAMA 23, 1007-1015.

Murphy, D.D., Segal, M., 1997. Morphological plasticity of dendritic spines in central neurons is mediated by activation of cAMP response element binding protein. Proc. Natl. Acad. Sci. USA 94, 1482-1487.

Murphy, D.D., Cole, N.B., Segal, M., 1998. Brain-derived neurotrophic factor mediates estradiol-induced dendritic spine formation in hippocampal neurons. Proc. Natl. Acad. Sci. USA 95, 11412-11417.

Naftolin, F., 1994. Brain aromatization of androgens. J. Reprod. Med. 39, 257-261.

National Institute for Neurologic Disorders and Stroke, 1999. Stroke: Hope through research. NIH Publication No. 99-2222.

Nichols, N.R., 1999. Glial responses to steroids as markers of brain aging. J. Neurobiol. 40, 585-601.

Nishino, H., Nakajima, K., Kumazaki, M., Fukuda, A., Muramatsu, K., Deshpande, S.B., Inubushi, T., Morikawa, S., Borlongan, C.V., Sanberg, P.R., 1998. Estrogen protects against while testosterone exacerbates vulnerability of the lateral striatal artery to chemical hypoxia by 3-nitropropionic acid. Neurosci. Res. 30, 303-312.

Nopoulos, P., Flaum, M., Andreasen, N.C., 1997. Sex differences in brain morphology in schizophrenia. Am. J. Psychiatry 154, 16481654.

Nordeen, E.J., 1990. Neurogenesis and sensitive periods in avian song learning. Trends Neurosci. 13, 31-36.

Oestreicher, A.B., De Graan, P.N., Gispen, W.H., Verhaagen, J., Schrama, L.H., 1997. B-50, the growth associated protein-43: modulation of cell morphology and communication in the nervous system. Prog. Neurobiol. 53, 627-686.

Ogawa, S., Lubahn, D.B., Korach, K.S., Pfaff, D.W., 1997. Behavioral effects of estrogen receptor gene disruption in male mice. Proc. Natl. Acad. Sci. USA 94, 1476-1481.

Ogawa, S., Washburn, T.F., Taylor, J., Lubahn, D.B., Korach, K.S., Pfaff, D.W., 1998. Modifications of testosterone-dependent behaviors by estrogen receptor- alpha gene disruption in male mice. Endocrinology 139, 5058-5069.

Ogawa, S., Chan, J., Chester, A.E., Gustafsson, J.A., Korach, K.S., Pfaff, D.W., 1999. Survival of reproductive behaviors in estrogen receptor beta gene-deficient ( $\beta$ ERKO) male and female mice. Proc. Natl. Acad. Sci. USA 96, 12887-12892.

Ojeda, S.R., Ma, Y.J., 1999. Glial-neuronal interactions in the neuroendocrine control of mammalian puberty: facilitatory effects of gonadal steroids. J. Neurobiol. 40, 528-540.

O'Keefe, J.A., Handa, R.J., 1990. Transient elevation of estrogen receptors in the neonatal rat hippocampus. Dev. Brain Res. 57, $119-127$.

O'Keefe, J.A., Li, Y., Burgess, L., Handa, R.J., 1995. Estrogen receptor mRNA alterations in the developing rat hippocampus. Mol. Brain Res. 30, 115-124.

Paech, K., Webb, P., Kuiper, G.G., Nilsson, S., Gustafsson, J., Kushner, P.J., Scanlan, T.S., 1997. Differential ligand activation of estrogen receptors ER $\alpha$ and ER $\beta$ at AP1 sites. Science 277, $1508-1510$

Paganini-Hill, A., 1995. Estrogen replacement therapy and stroke. Prog. Cardiovasc. Dis. 38, 223-242.

Paganini-Hill, A., Henderson, V.W., 1996. Estrogen replacement therapy and risk of Alzheimer disease. Arch. Intern. Med. 156, 2213-2217.

Paganini-Hill, A., Ross, R.K., Henderson, B.E., 1988. Postmenopausal oestrogen treatment and stroke: a prospective study. BMJ 297, 519-522.

Palmer, T.D., Markakis, E.A., Willhoite, A.R., Safar, F., Gage, F.H., 1999. Fibroblast growth factor-2 activates a latent neurogenic program in neural stem cells from diverse regions of the adult CNS. J. Neurosci. 19, 8487-8497.
Panickar, K.S., Guan, G., King, M.A., Rajakumar, G., Simpkins, J.W., 1997. 17ß-Estradiol attenuates CREB decline in the rat hippocampus following seizure. J. Neurobiol. 33, 961-967.

Patrone, C., Andersson, S., Korhonen, L., Lindholm, D., 1999. Estrogen receptor-dependent regulation of sensory neuron survival in developing dorsal root ganglion. Proc. Natl. Acad. Sci. USA 96, 10905-10910.

Pedersen, P.M., Jorgensen, H.S., Nakayama, H., Raaschou, H.O., Olsen, T.S., 1995. Aphasia in acute stroke: incidence, determinants, and recovery. Ann. Neurol. 38, 659-666.

Pelligrino, D.A., Santizo, R., Baughman, V.L., Wang, Q., 1998. Cerebral vasodilating capacity during forebrain ischemia: effects of chronic estrogen depletion and repletion and the role of neuronal nitric oxide synthase. NeuroReport 9, 3285-3291.

Perez, J., Kelly, D.B., 1996. Trophic effects of androgen receptor expression and the survival of laryngeal motor neurons after axotomy. J. Neurosci. 16, 6625-6633.

Perez, J., Kelly, D.B., 1997. Androgen mitigates axotomy-induced decreases in calbindin expression in motor neurons. J. Neurosci. 17, 7396-7403.

Petersen, D.N., Tkalcevic, G.T., Koza-Taylor, P., Turi, T.G., Brown, T.A., 1998. Identification of estrogen receptor $\beta 2$, a functional variant of estrogen receptor $\beta$ expressed in normal rat tissues. Endocrinology 139, 1082-1092.

Pettersson, K., Grandien, K., Kuiper, G.G, Gustaffson, J.A., 1997. Mouse estrogen receptor beta forms estrogen response elementbinding heterodimers with estrogen receptor alpha. Mol. Endocrinol. 11, 1486-1496.

Petitti, D.B., Sidney, S., Bernstein, A., Wolf, S., Quesenberry, C., Ziel, H.K., 1996. Stroke in users of low-dose oral contraceptives. N. Engl. J. Med. 335, 8-15.

Petitti, D.B., Sidney, S., Quesenberry, C.P., Bernstein, A., 1998. Ischemic stroke and use of estrogen and estrogen/progestogen as hormone replacement therapy. Stroke 29, 23-28.

Pfaff, D., Keiner, M., 1973. Atlas of estradiol-concentrating cells in the central nervous system of the female rat. J. Comp. Neurol. 151, 121-158.

Pike, C.J., 1999. Estrogen modulates neuronal Bcl-XL expression and beta-amyloid-induced apoptosis: relevance to Alzheimer's disease. J. Neurochem. 72, 1552-1563.

Pizzamiglio, L., Mammucari, A., Razzano, C., 1985. Evidence for sex differences in brain organization in recovery in aphasia. Brain Lang. 25, 213-223.

Pohjalainen, T., Rinne, J.O., Nagren, K., Syvalahti, E., Hietala, J., 1998. Sex differences in the striatal dopamine D2 receptor binding characteristics in vivo. Am. J. Psychiatry 155, 768-773.

Poirier, J., 1994. Apolipoprotein E in animal models of CNS injury and in Alzheimer's disease. Trends Neurosci. 17, 525-530.

Pons, S., Torres-Aleman, I., 1993. Estradiol modulates insulin-like growth factor I receptors and binding proteins in neurons from the hypothalamus. Neuroendocrinology 5, 267-271.

Popko, B., Goodrum, J.F., Bouldin, T.W., Zhang, S.H., Maeda, N., 1993. Nerve regeneration occurs in the absence of apolipoprotein E in mice. J. Neurochem. 60, 1155-1158.

Pozzo-Miller, L.D., Inoue, T., Murphy, D.D., 1999. Estradiol increases spine density and NMDA-dependent $\mathrm{Ca}^{2+}$ transients in spines of CA1 pyramidal neurons from hippocampal slices. J. Neurophysiol. 81, 1404-1411.

Puy, L., MacLusky, N.J., Becker, L., Karsan, N., Trachtenberg, J., Brown, T.J., 1995. Immunocytochemical detection of androgen receptor in human temporal cortex characterization and application of polyclonal androgen receptor antibodies in frozen and paraffin-embedded tissues. J. Steroid Biochem. Mol. Biol. 55, 197-209.

Raap, D.K., DonCarlos, L., Garcia, F., Muma, N.A., Wolf, W.A., Battaglia, G., van de Kar, L.D., 2000. Estrogen desensitizes 5- 
HT1A receptors and reduces levels of Gz, Gi1, and Gi3 proteins in the hypothalamus. Neuropharmacology, in press.

Rabbani, O., Panickar, K.S., Rajakumar, G., King, M.A., Bodor, N., Meyer, E.M., Simpkins, J.W., 1997. 17ß-Estradiol attenuates fimbrial lesion-induced decline of ChAT-immunoreactive neurons in the rat medial septum. Exp. Neurol. 146, 179-186.

Ramirez, V.D., Zheng, J., 1996. Membrane sex-steroid receptors in the brain. Front. Neuroendocrinol. 17, 402-439.

Razandi, M., Pedram, A., Greene, G.L., Levin, E.R., 1999. Cell membrane and nuclear estrogen receptors (ERs) originate from a single transcript: studies of ER- $\alpha$ and ER- $\beta$ expressed in Chinese hamster ovary cells. Mol. Endocrinol. 13, 307-319.

Regan, R.F., Guo, Y., 1997. Estrogens attenuate neuronal injury due to hemoglobin, chemical hypoxia, and excitatory amino acids in murine cortical cultures. Brain Res. 764, 133-140.

Resnick, S.M., Maki, P.M., Golski, S., Kraut, M.A., Zonderman, A.B., 1998. Effects of estrogen replacement therapy on PET cerebral blood flow and neuropsychological performance. Horm. Behav. 34, 171-182.

Rissanen, A., Puolivali, J., van Groen, T., Riekkinen, P., 1999. In mice tonic estrogen replacement therapy improves non-spatial and spatial memory in a water maze task. NeuroReport 10 , 1369-1372.

Rissman, E.F., Early, A.H., Taylor, J.A., Korach, K.S., Lubahn, D.B., 1997. Estrogen receptors are essential for female sexual receptivity. Endocrinology 138, 507-510.

Roof, R.L., Duvdevani, R., Stein, D.G., 1993a. Gender influences outcome of brain injury: progesterone plays a protective role. Brain Res. 607, 333-336.

Roof, R.L., Zhang, Q., Glasier, M.M., Stein, D.G., 1993b. Genderspecific impairment on Morris water maze task after entorhinal cortex lesion. Behav. Brain Res. 57, 47-51.

Roof, R.L., Duvdevani, R., Braswell, L., Stein, D.G., 1994. Progesterone facilitates cognitive recovery and reduces secondary neuronal loss caused by cortical contusion injury in male rats. Exp. Neurol. 129, 64-69.

Roof, R.L., Hoffman, S.W., Stein, D.G., 1997. Progesterone protects against lipid peroxidation following traumatic brain injury in rats. Mol. Chem. Neuropathol. 31, 1-11.

Rusa, R., Alkayed, N.J., Crain, B.J., Traystman, R.J., Kimes, A.S., London, E.D., Klaus, J.A., Hurn, P.D., 1999. 17ß-Estradiol reduces stroke injury in estrogen-deficient female animals. Stroke $30,1665-1670$.

Sabbah, M., Courilleau, D., Mester, J., Redeuilh, G., 1999. Estrogen induction of the cyclin D1 promoter: involvement of a cAMP response-like element. Proc. Natl. Acad. Sci. USA 96, 11217-11222.

Santizo, R., Pelligrino, D.A., 1999. Estrogen leukocyte adhesion in the cerebral circulation of female rats. J. Cereb. Blood Flow Metab. 19, 1061-1065.

Sarno, M.T., Buonaguro, A., Levita, E., 1985. Gender and recovery from aphasia after stroke. J. Nerv. Ment. Dis. 173, 605-609.

Sawada, H., Ibi, M., Kihara, T., Urushitani, M., Akaike, A., Shimohama, S., 1998. Estradiol protects mesencephalic dopaminergic neurons from oxidative stress-induced neuronal death. J. Neurosci. Res. 54, 707-719.

Schehter, I., Schejter, J., Abarbanel, M., Koren, R., Mendelson, L., Ring, H., Becker, E., 1985. Sex and aphasic syndromes. Scand. J. Rehabil. Med. Suppl. 12, 64-67.

Schmidt, R., Fazekas, F., Reinhart, B., Kapeller, P., Fazekas, G., Offenbacher, H., Eber, B., Schumacher, M., Freidl, W., 1996. Estrogen replacement therapy in older women: a neuropsychological and brain MRI study. J. Am. Geriatr. Soc. 44, 1307-1313.

Seeman, M.V., 1997. Psychopathology in women and men: focus on female hormones. Am. J. Psychiatry 154, 1641-1647.

Sheng, H., Laskowitz, D.T., Mackensen, G.B., Kudo, M., Pearlstein, R.D., Warner, D.S., 1999. Apolipoprotein E deficiency worsens outcome from global cerebral ischemia in the mouse. Stroke 30, $1118-1124$.

Shi, J., Zhang, Y.Q., Simkis, J.W., 1997. Effects of 17ß-Estradiol on glucose transporter 1 expression and endothelial cell survival following focal ischemia in the rats. Exp. Brain Res. 117, 200-206.

Shi, J., Panickar, K.S., Yang, S.H., Rabbani, O., Day, A.L., Simpkins, J.W., 1998. Estrogen attenuates over-expression of beta-amyloid precursor protein messager RNA in an animal model of focal ischemia. Brain Res. 810, 87-92.

Shughrue, P.J., Dorsa, D.M., 1993. Estrogen modulates the growthassociated protein GAP-43 (neuromodulin) mRNA in the rat preoptic area and basal hypothalamus. Neuroendocrinology 57, 439447.

Shughrue, P.J., Stumpf, W.E., MacLusky, N.J., Zielinski, J.E., Hochberg, R.B., 1990. Developmental changes in estrogen receptors in mouse cerebral cortex between birth and postweaning: studied by autoradiography with $11 \beta$-methoxy-16 $\alpha$ [ ${ }^{125}$ I]iodoestradiol. Endocrinology 126, 1112-1124.

Shughrue, P.J., Bushnell, C.D., Dorsa, D.M., 1992. Estrogen receptor messenger ribonucleic acid in female rat brain during the estrous cycle: a comparison with ovariectomized females and intact males. Endocrinology 131, 381-388.

Shughrue, P.J., Lane, M.V., Merchenthaler, I., 1997a. Regulation of progesterone receptor messenger ribonucleic acid in the rat medial preoptic nucleus by estrogenic and antiestrogenic compounds: an in situ hybridization study. Endocrinology 138, 5476-5484.

Shughrue, P.J., Lane, M.V., Merchenthaler, I., 1997b. Comparative distribution of estrogen receptor-alpha and -beta mRNA in the rat central nervous system. J. Comp. Neurol. 388, 507-525.

Shughrue, P.J., Lubahn, D.B., Negro-Vilar, A., Korach, K.S., Merchenthaler, I., 1997c. Responses in the brain of estrogen receptor alpha-disrupted mice. Proc. Natl. Acad. Sci. USA 94, 11008-11012.

Shughrue, P., Scrimo, P., Lane, M., Askew, R., Merchenthaler, I., 1997d. The distribution of estrogen receptor- $\beta$ mRNA in forebrain regions of the estrogen receptor- $\alpha$ knockout mouse. Endocrinology 138, 5649-5652.

Shughrue, P.J., Scrimo, P.J., Merchenthaler, I., 1998. Evidence for the colocalization of estrogen receptor- $\beta$ mRNA and estrogen receptor- $\alpha$ immunoreactivity in neurons of the rat forebrain. Endocrinology 139, 5267-5270.

Shyamala, G., Guiot, M.C., 1992. Activation of kappa B-specific proteins by estradiol. Proc. Natl. Acad. Sci. USA 89, 1062810632.

Simerly, R.B., 1990. Hormonal control of neuropeptide gene expression in sexually dimorphic olfactory pathways. Trends Neurosci. 13, 104-110.

Simerly, R.B., Young, B.J., 1991. Regulation of estrogen receptor messenger ribonucleic acid in rat hypothalamus by sex steroid hormones. Mol. Endocrinol. 5, 424-432.

Simpkins, J.W., Green, P.S., Gridley, K.E., Singh, M., de Fiebre, N.C., Rajakumar, G., 1997a. Role of estrogen replacement therapy in memory enhancement and the prevention of neuronl loss associated with Alzheimer's disease. Am. J. Med. 103, 19S$25 \mathrm{~S}$.

Simpkins, J.W., Rajakumar, G., Zhang, Y.Q., Simpkins, C.E., Greenwald, D., Yu, C.J., Bodor, N., Day, A.L., 1997b. Estrogens may reduce mortality and ischemic damage caused by middle cerebral artery occlusion in the female rat. J. Neurosurg. 87, 724 730.

Singer, C.A., Pang, P.A., Dobie, D.J., Dorsa, D.M., 1996a. Estrogen increases GAP-43 (neuromodulin) mRNA in the preoptic area of aged rats. Neurobiol. Aging 17, 661-663.

Singer, C.A., Rogers, K.L., Strickland, T.M., Dorsa, D.M., 1996 b. Estrogen protects primary cortical neurons from glutamate toxicity. Neurosci. Lett. 212, 13-16.

Singer, C.A., Rogers, K.L., Dorsa, D.M., 1998. Modulation of Bcl-2 
expression: a potential component of estrogen protection in NT2 neurons. NeuroReport 9, 2565-2568.

Singer, C.A., Figueroa-Masot, X.A., Batchelor, R.H., Dorsa, D.M., 1999. The mitogen-activated protein kinase pathway mediates estrogen neuroprotection after glutamate toxicity in primary cortical neurons. J. Neurosci. 19, 2455-2463.

Singh, M., Meyer, E.M., Simpkins, J.W., 1995. The effect of ovariectomy and estradiol replacement on brain-derived neurotrophic factor messenger ribonucleic acid expression in cortical and hippocampal brain regions of female Sprague-Dawley rats. Endocrinology 136, 2320-2324.

Singh, M., Setalo, G., Guan, X., Warren, M., Toran-Allerand, C.D., 1999. Estrogen-induced activation of mitogen-activated protein kinase in cerebral cortical explants: convergence of estrogen and neurotrophin signaling pathways. J. Neurosci. 19, 1179-1188.

Slooter, A.J., Bronzova, J., Witteman, J., Van Broeckhoven, C., Hofman, A., van Duijn, C.M., 1999. Estrogen use and early onset Alzheimer's disease: a population-based study. J. Neurol. Neurosurg. Psychiatry 67, 779-781.

Smith, S.S., Waterhouse, B.D., Woodward, D.J., 1987. Sex steroid effects on extrahypothalamic CNS. I. Estrogen augments neuronal responsiveness to iontophoretically applied glutamate in the cerebellum. Brain Res. 422, 40-51.

Smith, S.S., Waterhouse, B.D., Woodward, D.J., 1988. Locally applied estrogens potentiate glutamate-evoked excitation of cerebellar Purkinje cells. Brain Res. 475, 272-282.

Sohrabji, F., Greene, L.A., Miranda, R.C., Toran-Allerand, C.D., 1994a. Reciprocal regulation of estrogen and NGF receptors by their ligands in PC12 cells. J. Neurobiol. 25, 974-988.

Sohrabji, F., Miranda, R.C., Toran-Allerand, C.D., 1994b. Estrogen differentially regulates estrogen and nerve growth factor receptor mRNAs in adult sensory neurons. J. Neurosci. 14, 459-471.

Sohrabji, F., Miranda, R.C., Toran-Allerand, C.D., 1995. Identification of a putative estrogen response element in the gene encoding brain-derived neurotrophic factor. Proc. Natl. Acad. Sci. USA 92, 11110-11114.

Stein, D.G., Fulop, Z.L., 1998. Progesterone and recovery after traumatic brain injury: an overview. The Neuroscientists 4, 435-442.

Stone, D.J., Rozovsky, I., Morgan, T.E., Anderson, C.P., Hajain, H., Finch, C.E., 1997. Astrocytes and microglia respond to estrogen with increased ApoE mRNA in vivo and in vitro. Exp. Neurol. 143, 313-318.

Stone, D.J., Rozovsky, I., Morgan, T.E., Anderson, C.P., Finch, C.E., 1998a. Increased synaptic sprouting in response to estrogen via an apolipoprotein E-dependent mechanism: implications for Alzheimer's disease. J. Neurosci. 18, 3180-3185.

Stone, D.J., Song, Y., Anderson, C.P., Krohn, K.K., Finch, C.E., Rozovsky, I., 1998b. Bidirectional transcription regulation of glial fibrillary acidic protein by estradiol in vivo and in vitro. Endocrinology 139, 3202-3209.

Sudo, S., Wen, T.C., Desaki, J., Matsuda, S., Tanaka, J., Arai, T., Maeda, N., Sakanaka, M., 1997. $\beta$-Estradiol protects hippocampal CAl neurons against transient forebrain ischemia in gerbil. Neurosci. Res. 29, 345-354.

Taleghany, N., Sarajari, S., DonCarlos, L.L., Gollapudi, L., Oblinger, M.M., 1999. Differential expression of estrogen receptor alpha and beta in rat dorsal root ganglion neurons. J. Neurosci. Res. 57, 603-615.

Tanapat, P., Hastings, N.B., Reeves, A.J., Gould, E., 1999. Estrogen stimulates a transient increase in the number of new neurons in the dentate gyrus of the adult female rat. J. Neurosci. 19, 57925901.

Tang, M.X., Jacobs, D., Stern, Y., Marder, K., Schofield, P., Gurland, B., Andrews, H., Mayeux, R., 1996. Effect of oestrogen during menopause on risk and age at onset of Alzheimer's disease. Lancet 348, 429-432.

Tanzer, L., Jones, K.J., 1997. Gonadal steroid regulation of hamster facial nerve regeneration: effects of dihydrotestosterone and estradiol. Exp. Neurol. 146, 258-264.

Tanzer, L., Sengelaub, D.R., Jones, K.J., 1999. Estrogen receptor expression in the facial nucleus of adult hamsters: does axotomy recapitulate development? J. Neurobiol. 39, 438-446.

Teixeira, C., Reed, J.C., Pratt, M.A.C., 1995. Estrogen promotes hemotherapeutic drug resistance by a mechanism involving bcl-2 proto-oncogene expression in human breast cancer cells. Cancer Res. 55, 3902-3907.

Tetel, M.J., Blaustein, J.D., 1991. Immunocytochemical evidence for noradrenergic regulation of estrogen receptor concentrations in the guinea pig hypothalamus. Brain Res. 565, 321-329.

Teter, B., Harris-White, M.E., Frautschy, S.A., Cole, G.M., 1999. Role of apolipoprotein $\mathrm{E}$ and estrogen in mossy fiber sprouting in hippocampal slice cultures. Neuroscience 91, 1009-1016.

Thornton, J.E., Nock, B., McEwen, B.S., Feder, H.H., 1986. Estrogen induction of progestin receptors in microdissected hypothalamic and limbic nuclei of female guinea pigs. Neuroendocrinology 43, 182-188.

Toran-Allerand, C.D., 1996. Mechanisms of estrogen action during neural development: mediation by interactions with the neurotrophins and their receptors? J. Steroid Biochem. Mol. Biol. 56, $169-178$.

Toran-Allerand, C.D., Ellis, L., Pfenninger, K.H., 1988. Estrogen and insulin synergism in neurite growth enhancement in vitro: mediation of steroid effects by interactions with growth factors? Brain Res. 469, 87-100.

Toran-Allerand, C.D., Miranda, R.C., Bentham, W.D., Sohrabji, F., Brown, T.J., Hochberg, R.B., MacLusky, N.J., 1992a. Estrogen receptors colocalize with low-affinity nerve growth factor receptors in cholinergic neurons of the basal forebrain. Proc. Natl. Acad. Sci. USA 89, 4668-7462.

Toran-Allerand, C.D., Miranda, R.C., Hochberg, R.B., MacLusky, N.J., 1992b. Cellular variations in estrogen receptor mRNA translation in the developing brain: evidence from combined $\left.{ }^{125} \mathrm{I}\right]$ estrogen autoradiography and non-isotopic in situ hybridization histochemistry. Brain Res. 576, 25-41.

Toran-Allerand, C.D., Singh, M., Setalo, G., 1999. Novel mechanisms of estrogen action in the brain: new players in an old story. Front. Neuroendocrinol. 20, 97-121.

Torres-Aleman, I., Naftolin, F., Robbins, R.J., 1990. Trophic effects of insulin-like growth factor-I on fetal rat hypothalamic cells in culture. Neuroscience 35, 601-608.

Torres-Aleman, I., Pons, S., Arevalo, M.A., 1994. The insulin-like growth factor I system in the rat cerebellum: developmental regulation and role in neuronal survival and differentiation. $J$. Neurosci. Res. 39, 117-126.

Toung, T.J., Traystman, R.J., Hurn, P.D., 1998. Estrogen-mediated neuroprotection after experimental stroke in male rats. Stroke 29, 1666-1670.

Tsai, M.J., O’Malley, B.W., 1994. Molecular mechanisms of action of steroid/thyroid receptor superfamily members. Annu. Rev. Biochem. 63, 451-486.

Vardimon, L., Ben-Dror, I., Avisar, N., Oren, A., Shiftan, L., 1999. Glucocorticoid control of glial gene expression. J. Neurobiol. 40, 513-527.

Vedder, H., Anthes, N., Stumm, G., Wurz, C., Behl, C., Krieg, J.C., 1999. Estrogen hormones reduce lipid peroxidation in cells and tissues of the central nervous system. J. Neurochem. 72, 25312538 .

Vegeto, E., Pollio, G., Pellicciari, C., Maggi, A., 1999. Estrogen and progesterone induction of survival of monoblastoid cells undergoing TNF- $\alpha$-induced apoptosis. FASEB J. 13, 793-803.

Wagner, C.K., Silverman, A.J., Morrell, J.I., 1998. Evidence for estrogen receptor in cell nuclei and axon terminals within the lateral habenula of the rat: regulation during pregnancy. J. Comp. Neurol. 392, 330-342. 
Walton, M.R., Dragunow, M., 2000. Is CREB a key to neuronal survival? Trends Neurosci. 23, 48-53.

Wang, Q., Santizo, R., Baughman, V.L., Pelligrino, D.A., Iadecola, C., 1999. Estrogen provides neuroprotection in transient forebrain ischemia through perfusion-independent mechanisms in rats. Stroke 30, 630-637.

Warembourg, M., Logeat, F., Milgrom, E., 1986. Immunocytochemical localization of progesterone receptor in the guinea pig central nervous system. Brain Res. 384, 121-131.

Warembourg, M., Jolivet, A., Milgrom, E., 1989. Immunohistochemical evidence of the presence of estrogen and progesterone receptors in the same neurons of the guinea pig hypothalamus and preoptic area. Brain Res. 480, 1-15.

Waring, S.C., Rocca, W.A., Petersen, R.C., O’Brien, P.C., Tangalos, E.G., Kokmen, E., 1999. Postmenopausal estrogen replacement therapy and risk of AD: a population-based study. Neurology 52, 965-970.

Watters, J.J., Dorsa, D.M., 1998. Transcriptional effects of estrogen on neurotensin gene expression involve cAMP/protein kinase Adependent signaling mechanisms. J. Neurosci. 18, 6672-6680.

Watters, J.J., Campbell, J.S., Cunningham, M.J., Krebs, E.G., Dorsa, D.M., 1997. Rapid membrane effects of steroids in neuroblastoma cells: effects of estrogen on mitogen activated protein kinase signalling cascade and c-fos immediate early gene transcription. Endocrinology 138, 4030-4033.

Weaver, C.E., Park-Chung, M., Gibbs, T.T., Farb, D.H., 1997. 17ßEstradiol protects against NMDA-induced excitotoxicity by direct inhibition of NMDA receptors. Brain Res. 761, 338-341.

Webb, P., Nguyen, P., Valentine, C., Lopez, G.N., Kowk, G.R., McInerney, E., Katzenellenbogen, G.S., Enmark, E., Gustafsson, J.-A., Nilsson, S., Kushner, P.J., 1999. The estrogen receptor enhances AP-1 activity by two distinct mechanisms with different requirements for receptor transactivation functions. Mol. Endocrinol. 13, 1672-1685.

Weisz, A., Rosales, R., 1990. Identification of an estrogen response element upstream of the human c-fos gene that binds the estrogen receptor and the AP-1 transcription factor. Nucleic Acids Res. 18, 5097-5106.

Whitehouse, P.J., Price, D.L., Clark, A.W., Coyle, J.T., DeLong, M.R., 1981. Alzheimer disease: evidence for selective loss of cholinergic neurons in the nucleus basalis. Ann. Neurol. 10, 122126.

Wood, R.I., Newman, S.W., 1995. Androgen and estrogen receptors coexist within individual neurons in the brain of the Syrian hamster. Neuroendocrinology 62, 487-497.

Woolley, C.S., 1998. Estrogen-mediated structural and functional synaptic plasticity in the female rat hippocampus. Horm. Behav. $34,140-148$.

Xu, H., Gouras, G.K., Greenfield, J.P., Vincent, B., Naslund, J., Mazzarelli, L., Fried, G., Jovanovic, J.N., Seeger, M., Relkin, N.R., Liao, F., Checler, F., Buxbaum, J.D., Chait, B.T., Thinakaran, G., Sisodia, S.S., Wang, R., Greengard, P., Gandy, S., 1998a. Estrogen reduces neuronal generation of Alzheimer $\beta$ amyloid peptide. Nat. Med. 4, 447-451.
Xu, Y., Berelowitz, M., Bruno, J.F., 1998b. Characterization of the promoter region of the human somatostatin receptor subtype 2 gene and localization of sequences required for estrogen-responsiveness. Mol. Cell. Endocrinol. 139, 71-77.

Yaffe, K., Sawaya, G., Lieberburg, I., Grady, D., 1998. Estrogen therapy in postmenopausal women: effects on cognitive function and dementia. JAMA 279, 688-695.

Yeh, S., Miyamoto, H., Shima, H., Chang, C., 1998. From estrogen to androgen receptor: a new pathway for sex hormones in prostate. Proc. Natl. Acad. Sci., USA 95, 5527-5532.

Yokosuka, M., Okamura, H., Hayashi, S., 1995. Transient expression of estrogen receptor-immunoreactivity (ER-IR) in the layer V of the developing rat cerebral cortex. Dev. Brain Res. 84, 99-108.

Young, L.J., Huot, B., Nilsen, R., Wang, Z., Insel, T.R., 1996. Species differences in central oxytocin receptor gene expression: comparative analysis of promoter sequences. J. Neuroendocrinol. $8,777-783$.

Yu, W.A., 1989. Administration of testosterone attenuates neuronal loss following axotomy in the brain-stem motor nuclei of female rats. J. Neurosci. 9, 3908-3914.

Yu, Y.L., Wagner, G.C., 1994. Influence of gonadal hormones on sexual differences in sensitivity to methamphetamine-induced neurotoxicity. J. Neural Transm. Park Dis. Dement. Sect. 8, 215221.

Yu, Z., Zhou, D., Bruce-Keller, A.J., Kindy, M.S., Mattson, M.P., 1999. Lack of the p50 subunit of NF- $\mathrm{KB}$ increases the vulnerability of hippocampal neurons to excitotoxic injury. J. Neurosci. 19, 8856-8865.

Zaulyanov, L.L., Green, P.S., Simpkins, J.W., 1999. Glutamate receptor requirement for neuronal cell death from anoxia-reoxygenation: an in vitro model for assessment of the neuroprotective effects of estrogens. Cell. Mol. Neurobiol. 19, 705-718.

Zhang, Y.Q., Shi, J., Rajakumar, G., Day, A.L., Simpkins, J.W., 1998. Effects of gender and estradiol treatment on focal brain ischemia. Brain Res. 784, 321-324.

Zheng, J., Ramirez, V.D., 1997. Demonstration of membrane estrogen binding proteins in rat brain by ligand blotting using a $17 \beta-$ Estradiol- $\left[{ }^{125} \mathrm{I}\right]$ bovine serum albumin conjugate. J. Steroid Biochem. Mol. Biol. 62, 327-336.

Zhou, Y., Shughrue, P.J., Dorsa, D.M., 1995. Estrogen receptor protein is differentially regulated in the preoptic area of the brain and in the uterus during the rat estrous cycle. Neuroendocrinology 61, 276-283.

Zhou, Y., Watters, J.J., Dorsa, D.M., 1996. Estrogen rapidly induces the phosphorylation of the cAMP response element binding protein in rat brain. Endocrinology 137, 2163-2166.

Zhu, Y.S., Pfaff, D.W., 1995. DNA binding of hypothalamic nuclear proteins on estrogen response element and preproenkephalin promoter: modification by estrogen. Neuroendocrinology 62, 454466.

Zwain, I.H., Yen, S.S., 1999. Neurosteroidogenesis in astrocytes, oligodendrocytes, and neurons of cerebral cortex of rat brain. Endocrinology 140, 3843-3852. 